\title{
Oncoselectivity in Oncolytic Viruses against Colorectal Cancer
}

\author{
Steven J. Conrad, Karim Essani* \\ Laboratory of Virology Department of Biological Sciences, Western Michigan University, Kalamazoo, USA \\ Email: ${ }^{*}$ karim.essani@wmich.edu
}

Received 15 August 2014; revised 10 September 2014; accepted 6 October 2014

Copyright (C) 2014 by authors and Scientific Research Publishing Inc.

This work is licensed under the Creative Commons Attribution International License (CC BY). http://creativecommons.org/licenses/by/4.0/

(c) (i) Open Access

\begin{abstract}
In humans colorectal cancer (CRC) is a significant cause of morbidity and mortality. New treatment options are urgently needed to supplement existing therapies. Replication-competent oncolytic viruses (RCOVs) for the treatment of cancerous tumors in vivo is a relatively new therapeutic modality with great but largely unrealized potential against CRC. In the context of oncolytic virus safety, oncoselectivity is an important criterion. It is at the conceptual intersection of viral replication strategy and tumor cell biology that RCOVs acquire their oncoselectivity, and thus their safety. Every aspect of tumor molecular biology which distinguishes it from normal, non-neoplastic cells is a potential target for exploitation. In the first section of this review we will provide an explanation of some of the successful and widely used strategies for improving oncoselectivity in wild-type viruses to make them more suitable as RCOVs. In the second section we will describe some of the characteristics of CRC biology which can be exploited to provide oncoselectivity against CRC. Throughout the review examples of successfully-engineered RCOVs which embody the approach or strategy under discussion are noted. By showing what has been done, we hope to highlight what is possible and what remains to be done to generate oncoselective RCOVs for use against CRC in humans.
\end{abstract}

\section{Keywords}

Colorectal Cancer, Replication-Competent Oncolytic Virus, Oncoselectivity, Virotherapy

\section{Introduction}

In the year 2014 colorectal cancers (CRCs) will be responsible for approximately 1.2 million new cancer diagnoses globally, and approximately half that number of deaths [1]. In the United States CRC will be the

"Corresponding author. 
third-most prevalent cancer diagnosed in both men and women [2]. In the majority of these patients, distant metastases to the liver and (less frequently) the lungs will be the proximate cause of death [3]. CRC tumors are staged according to the degree of penetration of the intestinal lumen, with stage 0 being the presence of abnormal, neoplastic cells as a pre-invasive lesion while stage 4 indicates the tumor has penetrated the colonic wall and is present in nearby lymph nodes, with the probability of distant metastases [4]. The therapies currently available will produce meaningful responses (i.e., increases in mean survival time) in only about $60 \%$ of patients with advanced stage CRC disease [5], and for patients with distant metastases the five-year survival rate will be only about $12 \%$ [1].

Until the 1970s the therapeutic interventions for CRC were limited to the three options already in place for decades-surgical resection, radiotherapy and non-selective cytotoxic chemotherapy [6]. The available therapeutic options have recently increased to include "targeted" therapeutics such as small-molecule receptor-tyrosine kinase inhibitors [7], biologicals [8], and therapeutic gene delivery (gene therapy) by replication-incompetent viral vectors [9]. Even more exotic therapies are on the horizon, for example therapies based upon nanoparticles [10] [11], photodynamic activation of precursor drugs [12], focused ultrasound [13], and combinations of these and other therapeutic approaches [14]. Despite the promise of new therapies, the CRC morbidity and mortality statistics make clear the need for new therapies to supplement those already available.

Oncolytic virotherapy is a relatively new therapeutic modality which seeks to turn the cytolytic ability of replicating viruses against cancerous cells in vivo, while sparing non-cancerous cells. The potential of replicationcompetent oncolytic viruses (RCOVs) has only recently started to be realized. RCOVs offer many advantages when compared to traditional cancer therapeutics, including reduced adverse effects due to toxicity, the possibility of broad applicability to many cancer types, and a self-amplifying mode of action which can produce more of the therapeutic virus at the expense of tumor cells.

Although the principle was formally stated over a century ago [15], experimentation with RCOVs was limited to naturally-occurring viruses until relatively recently. The ongoing "molecular revolution" has fundamentally changed every aspect of biology, and enabled the rational design and production of bespoke viruses targeted at specific cancer types. A deluge of innovation in RCOV engineering followed. The first rationally designed RCOV was a recombinant herpesvirus (HSV-1) attenuated by deletion of the viral thymidine kinase (TK) to improve its oncoselectivity and was reported in 1991 [16]. The first RCOV to be approved by a national regulatory agency was H101, a recombinant adenovirus produced by Shanghai Sunway Biotech and approved by the China Food and Drug Administration in 2005 for use against head and neck cancer [17].

The developmental trajectory of oncolytic virotherapy is in some ways analogous to that of the earliest chemotherapeutic agents. Both were developed from starting materials which were not originally intended for cancer therapy and were not at all oncoselective in their mechanism of action. Improvements to oncoselectivity, safety and efficacy for both cancer chemotherapeutic agents and RCOVs became possible as the molecular basis of their therapeutic mechanism of action and the molecular biology of cancer became at least partially understood. The first widely-used cancer chemotherapeutic agents were derived from "nitrogen mustards," the vesicant (blistering) agents used as a chemical weapon during World War I [6] [18]. These compounds worked by alkylating biological macromolecules at sites favorable to nucleophilic attack (nitrogen, oxygen and sulfur atoms), but their most immediate cytotoxic effect was due to DNA alkylation, strand cross-linking and the subsequent mitotic catastrophe and necrotic cell death [19] [20]. When used against leukemias [21], what selectivity these compounds exhibited for cancer cells derived from the high mitotic index found within neoplastic tissues, and non-cancerous tissues with high numbers of mitotic cells (e.g., hair follicles and the intestinal epithelia) were also negatively impacted. Likewise, initial studies involving oncolytic virotherapy were done with wild-type viruses, sometimes in poorly-controlled clinical experiments that were occasionally lethal to the patient [22].

With the ability to manipulate, clone and sequence DNA it became possible to characterize viral genomes and to observe the results of genetic manipulation. The same technologies also made it possible to characterize the molecular level differences between the cancerous cells and normal somatic cells [23] [24]. Every difference between a cancerous cell and a non-cancerous cell is a potential target for therapeutic intervention which can be exploited in the rational design of RCOVs to increase their oncoselectivity and safety as cancer therapeutic agents.

The central challenge for RCOV design is achieving oncoselectivity [25]. This review attempts to reduce the sometimes bewildering array of approaches developed to endow a RCOV with oncoselectivity to a manageable number of conceptual categories. Presently, the best studied and most heavily utilized virus family in the context 
of RCOVs is the Adenoviridae, usually adenovirus serotype 5 (Ad5), but other serotypes have also been utilized [26]. Several favorable qualities of the adenoviruses have made them the workhorse virus for both gene therapy and RCOV research. These include their small and well-characterized genomes, the degree to which their molecular mechanisms of host cell entry are understood, the ease with which that cell tropism can be modified, their nuclear site of genomic replication, and the extreme ease with which recombinant viruses can be made [27] [28].

Oncoselectivity is achieved when a RCOV exhibits an increased tendency to replicate in and destroy cancerous cells over non-cancerous cells. Oncoselectivity is the most important quality of an oncolytic virus because safety and oncoselectivity go hand in hand. Broadly speaking, there are two approaches to improving the oncoselectivity of a given virus. The first approach is to change the entry tropism of the virus (i.e., change the cell type it enters most efficiently) such that it can only bind to and enter a targeted cancer cell type which displays some specific receptor at its surface. The second approach is to increase the efficiency of replication in cancerous cells or to reduce the efficiency of replication in non-cancerous cells, or both. Obviously, a virus which can only enter cancerous cells can only replicate in cancerous cells. If it was possible to engineer a virus with this property the virus would be perfectly oncoselective. Likewise, a virus which enters all cell types without discrimination but is only capable of replication in cancerous cells could also be described as perfectly oncoselective (assuming the harm to non-cancerous cells during abortive viral replication would be negligible, which is not always the case). In practice these two approaches are often used together, and neither approach has been used to achieve perfect oncoselectivity. The changes which can be made to improve the oncoselectivity and safety profile of engineered RCOVs are described below. A conceptual map of current oncoselectivity strategies is provided as Figure 1.

\section{Oncoselectivity through Viral Attenuation}

One approach to limiting viral replication to cancerous cells is through attenuation of the RCOV via deletion of viral genes. Two broad strategies exist under the heading of viral attenuation: Attenuation by ablation or deletion of metabolically significant gene(s), and ablation of genes used by the virus to blunt the host cell innate antiviral response, deletion of which results in a "disarmed" virus which is able to replicate efficiently only in cells deficient in some host antiviral defense (e.g., the interferon response). Attenuation strategies are especially important

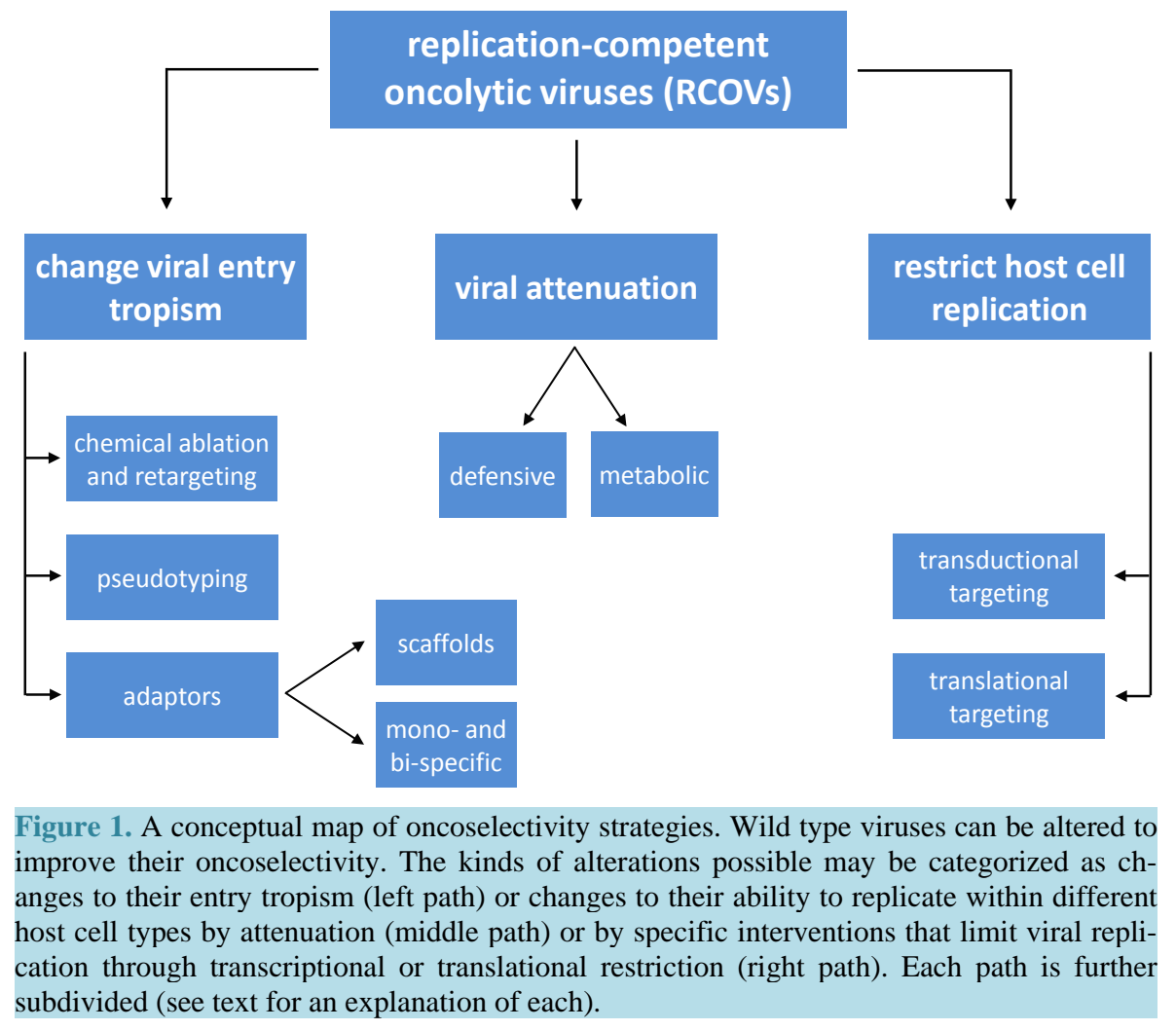


in viruses which do not replicate in the nucleus and are therefore not exposed to host-cell transcription factors. Such viruses are not amenable to the transcriptional targeting approach often used to increase oncoselectivity in RCOVs (detailed below). The poxviruses are an example of viruses which replicate entirely within the host cell cytoplasm [29], and the complexity of poxvirus host cell entry [30] and its interaction with the nearly-ubiquitous heparin sulfate at the host cell surface [31] makes alteration of their entry tropism difficult.

As stated earlier, the first modern RCOV was a herpesvirus in which the viral TK was deleted to reduce replication in normal, post-mitotic cells [16]. Normal, post-mitotic cells do not usually have large cytoplasmic pools of nucleoside monophosphates ready for phosphorylation to their triphosphate forms, but cancerous cells tend to have greater amounts of this necessary and rate-limiting precursor [32]. Indeed, the constitutive expression TK1 has been proposed as a universal biomarker of neoplastic cells [33], and ablation or deletion of a viral TK decreases the efficiency of viral replication in normal post-mitotic cells but does not significantly slow viral replication in cancerous cells because the amount of available thymidine monophosphate is not a limiting factor for viral DNA synthesis. This attenuation strategy has been demonstrated in a variety of virus families, including the poxviruses. The poxvirus RCOV JX-594, derived from the vaccinia virus (VACV), New York City Board of Health/Wyeth strain [34], has been clinically trialed against CRC [35] and has been shown to replicate preferentially in cells with high levels of TK expression [35].

\section{Oncoselectivity through Alteration of Viral Tropism}

Viral entry into a host cell is a complex multistep process which varies greatly with the virus family and type, but most animal virus infections begin with viral adsorption to a host cell membrane [36] [37]. Changing the binding proteins displayed at the virion surface can alter the tropism of the virus. This practice is sometimes referred to as "transductional retargeting" or simply "retargeting" and it is used when a change to the native or "natural" entry tropism of a potential oncolytic virus is needed to target a particular tumor cell type. There are several ways to retarget a virus, and all involve either the ablation of the existing viral entry tropism or the addition of new viral entry tropism determinants, or both. Examples of each are discussed below.

\subsection{Chemical Masking, Detargeting and Retargeting}

Most virus families rely upon a specific interaction between protein ligand(s) arrayed at the viral surface and specific host cell-surface receptors to initiate entry into the host cell and begin the infection cycle [36] [37]. It is possible to ablate the native tropism of a virus using purely chemical means. A virus devoid of its native tropism is said to be "detargeted" [38]. Hydrophilic polymers such as reactive polyethylene glycol (PEG) [39], N-[2hydroxypropyl] methacrylamide (pHPMA) [40] [41], and various types of charged lipids [42] have all been shown to ablate ("mask") an existing viral tropism. PEG is an uncharged, hydrophilic, poorly immunogenic polymer which interferes with protein-protein interactions [43] [44]. When functionalized at the viral surface, these polymers or lipids stearically interfere with the viral ligands which would normally attach to the host cell receptors [45]. The same polymers and lipids can also provide a substrate for the attachment of new targeting moieties, resulting in a "retargeted" virus with a new host cell tropism. Most of the work done in this area has been with the adenoviruses, which have been used for decades as high-efficiency gene delivery vectors [46]. An example of chemical detargeting and retargeting is shown in Figure 2.

This approach to viral detargeting has been promising in oncolytic virology. For example, systemically-administered adenoviruses can accumulate in the liver and transfect non-target tissues [47], limiting their therapeutic potential. This problem has been addressed by the attachment of PEG or other polymers to viruses ("coating” them) before administration [48] [49]. Functionalization of a virus with PEG (PEGylation) can reduce its undesirable accumulation in and transduction of some non-target tissues, reduce its toxicity when administered in large amounts, reduce its immunogenicity (also referred to as “stealthing” or "shielding”), and increase its mean retention time in the plasma [40] [42].

The same coating molecules which mask and detarget a virus can also be used to retarget the virus by attachment of ligands to reactive sites on the coating molecules themselves [41]. For example, Green and colleagues wished to use the Ad5 to target cancerous cells which expressed the fibroblast growth factor receptor (FGFR). The normal receptor used by Ad5 for the initial host cell adsorption is the Coxsackievirus and adenovirus receptor (CAR) but expression of that receptor is sometimes downregulated in cancerous cells, making it an undesirable RCOV host cell tropism determinant for many cancer types [50] [51]. Green and colleagues first 


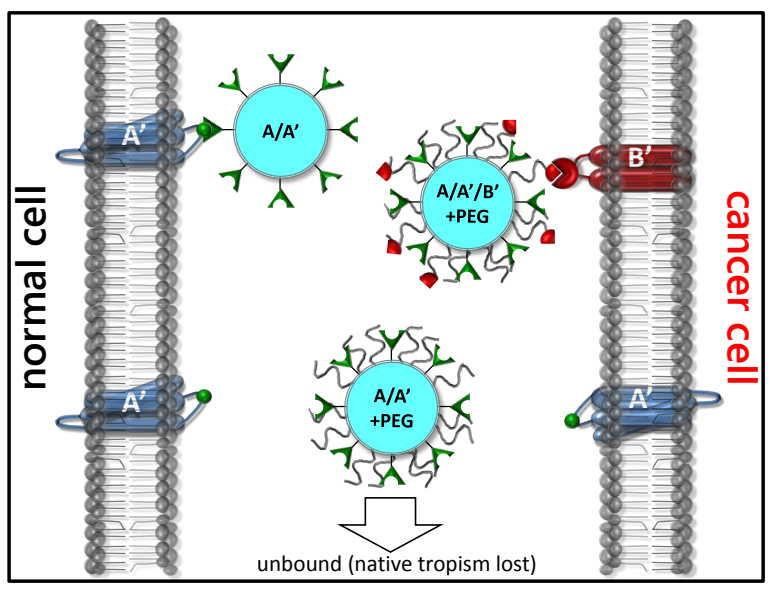

Figure 2. Chemical detargeting and retargeting. In the following examples, normal cells express the ubiquitous cell surface receptor A' (blue transmembrane receptor with green spherical binding site) while cancerous cells express the cancer-specific cell surface receptor B' (red transmembrane receptor with red pie-shaped antigen). Virus $A / A^{\prime}$ has a native tropism for antigen A', making it unsuitable for application as a virotherapeutic. The native tropism of wild-type virus A for cell-surface receptor A' can be erased by functionalization with various lipids or with PEG (gray strands). The functionalized virus (virus $\mathrm{A} / \mathrm{A}^{\prime}+\mathrm{PEG}$ ) has lost its native tropism due to steric interference with its cognate cell-surface receptor A' and is said to be "detargeted.” The detargeted virus now binds to all host cells much less efficiently than does the wild type. Virus A/A' + PEG can be retargeted towards the $\mathrm{B}^{\prime}$ receptor on cancerous cells by attachment of a ligand cognate to the cancer cell-specific cell-surface antigen B' (red wedge). Virus A/A'/B' retains its native genetic makeup but is now retargeted to cancerous cells through purely surface modification.

detargeted their virus by functionalization of the virion with pHPMA. To retarget the virus, they attached fibroblast growth factor (FGF) to the pHPMA coating via reaction between the reactive pHPMA and the amines of the FGF lysine residues. The resulting functionalized virus displayed an entry tropism for cells which express the FGFR. When the retargeted Ad5 was used with the murine CRC cell line MC26, the retargeted (FGF-conjugated) virus transfected these cells almost 100-fold more efficiently than did the wild-type Ad5 [41].

A significant disadvantage of this approach is that only viruses coated with the detargeting polymers and the retargeting ligands will display the desired tropism—all progeny virions will display the wild type tropism of the unmodified virus because no genetic changes have been made to the virus.

\subsection{Viral Pseudotyping}

All viruses have ligand molecules displayed at their surfaces whose purpose is to bind host cell receptors and begin the infection cycle [29] [30]. As in the above example of the Ad5 and its native CAR target, the native receptor for a potential RCOV can be downregulated in a particular cancer cell type, making the RCOV inefficient or unsuitable for virotherapy against cancers of that type. One way to address this problem is by viral pseudotyping. A pseudotyped virus is one in which the native determinant(s) of viral tropism are replaced with the tropism determinant ligands from a different virus whose tropism is against the desired target cell type. This can be done by chemical modification of the viral surface or by genetic alteration of the viral genes which encode the receptor binding ligands displayed at the viral surface. As noted above, only genetic alteration of the viral genome produces a retargeted virus which will produce re-targeted progeny virions ("multi-round" infection). As with chemical ablation and retargeting, this practice was first developed to alter the tropism of the viral vec- 
tors used in gene therapy (adenoviral, lentiviral and retroviral gene vectors) [52] [53], but has been successfully used in RCOVs of several types, most frequently the adenoviruses [54], and the herpesviruses [55].

A pseudotyped RCOV has been demonstrated by Mizuguchi and Hayakawa, who changed the native host cell binding specificity of the Ad5 serotype to that of the Ad35 serotype by the substitution of the knob and fiber region of Ad5 with Ad35 knob and fiber, while retaining the Ad5 fiber tail and penton base [56]. In this example, the native tropism of Ad5 for the CAR was genetically altered via the expression of a chimeric fiber which incorporated the CD46-binding portion of Ad35, thereby changing the tropism of the virus from the CAR to the cell-surface antigen CD46 and making it suitable for renal carcinoma cell entry [56]-[58]. The approach is shown schematically in Figure 3.

Work done with the vesicular stomatitis, serotype Indiana (VSIV) provides another excellent example of what is possible with viral pseudotyping. The VSIV is a "bullet-shaped," enveloped virus with a single-stranded negative-sense RNA genome of approximately $11 \mathrm{~kb}$ which contains only five genes [59]. In humans the VSIV does not routinely cause serious disease, but it is responsible for some economically important diseases of rodents and livestock, including horses, pigs and cattle [60] [61]. Replication of the VSIV in healthy human cells is usually prevented by the cellular induction of interferon $\alpha$ and $\beta$ (IFN $\alpha / \beta$ ) and by IFN activation of the PKR antiviral response [62]. Because this and other innate immune responses are often defective or absent in cancerous cells [63], the VSIV (along with the reoviruses and the paramyxoviruses) are sometimes referred to as having a "natural" or native oncolytic capacity [64]. This native oncolytic ability makes them potentially very useful as RCOVs, but in the case of the VSIV that potential is undercut by a very broad host tropism [65]. The most important determinant of host cell tropism in the VSIV is the VSIV glycoprotein G (VSV-G) [66]. Adsorption to host cells in the VSIV occurs through binding of the trimeric VSIV-G to a widely expressed receptor of low density lipids, accounting for the ability of VSIV to enter nearly all animal cells [67]. To narrow the host cell tropism of the VSIV and target it to distinct cancer cell types, several groups have replaced the VSIV-G with tropism determinant viral ligands native to other viruses. For example, Muik and colleagues [68] used a mutant of the VSIV which was deleted for its native tropism determinant and provided a new tropism by transfer of the lymphocytic choriomeningitis virus (LCMV) coat glycoprotein GP (LCMV-GP). Kretzschmar and colleagues [66] have demonstrated the addition of the influenza virus tropism determining glycoproteins hemagglutinin (HA) and neuraminidase (NA) to the VSIV. Ayala-Breton and colleagues [69] have shown that VSIV deleted for the VSIV-G can be retargeted using measles virus HA and fusion proteins which contain short regions of single-chain antibodies with specificities for the epidermal growth factor receptor (EGFR), prostate-specific antigen (PSA), or the folate receptor. In each of these cases the retargeted VSIV displayed improved specificity of infection for cells bearing the cognate receptor in vitro and (where tested) in vivo.

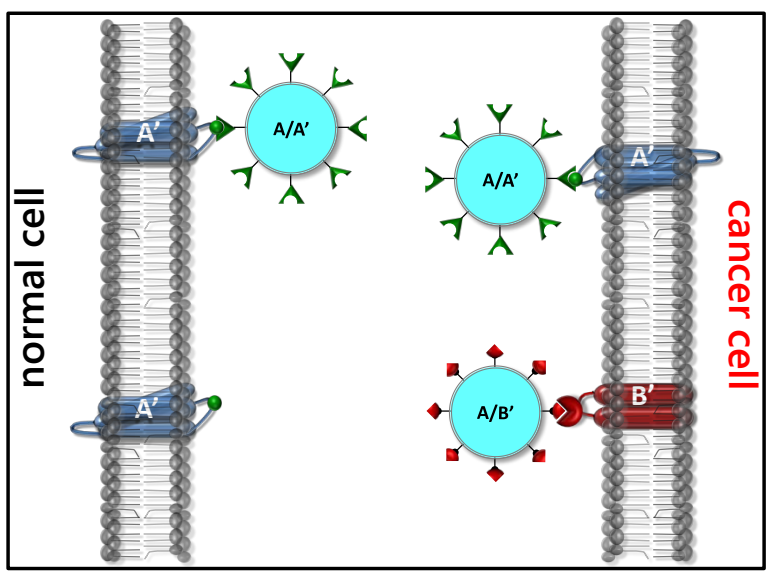

Figure 3. Pseudotyping. Virus A/A' can be genetically pseudotyped to express a binding protein cognate to cancer-cell specific antigen B' (red wedge). Virus A/B' has had its native tropism eliminated and is now retargeted towards cancer cell-surface antigen B'. Because the change was made at the genetic level, multi-round replication of the recombinant A/B' can occur. 


\subsection{Bridging Viruses to Their Cellular Targets (Scaffolds and Adaptors)}

Rather than changing a virus's tropism by substituting one tropism determinant for another, it is possible to attach the virus to the targeted cell type through molecules referred to as "adaptors". Adaptors usually have two binding specificities, one for the therapeutic virus and one for an antigen displayed on the targeted cell's surface. The two "arms" of the adaptor molecule form a "bridge" connecting the virus and the targeted cell. Adaptor binding brings the virus and the host cell into close proximity and causes the process of virus internalization to commence. This approach and practice has benefitted enormously from advances in engineered antibodies and antibody fragments, resulting in a truly amazing array of antibody-derived molecules that are now available [70].

As the examples cited below illustrate, many types of molecules can be used as adaptors, and adaptors can be either encoded into the viral genome for multi-round infections or added exogenously for single-round infections. For reasons of convenience it is sometimes desirable to keep one arm (i.e., one binding specificity) of an adaptor constant. If the virus-binding arm of an adaptor is constant, merely changing the host cell-binding arm will retarget the virus toward a different cell type. The constant virus-binding arm could be one-half of a high-affinity binding system (e.g., streptavidin/biotin or protein A/immunoglobulin). In practice, a virus may be "decorated" with (for example) avidin, and the adaptor in this case would have one arm composed of biotin, which would result in very high-affinity binding of the adaptor molecule to the avidin-decorated virus. In this example, the avidin is referred to as a "scaffold," because avidin can be used to decorate different viruses to achieve the same retargeting effect [71]. There are many examples of the successful use of adaptors to achieve viral retargeting.

Pereboeva and colleagues [72] have engineered a recombinant Ad5 which they retargeted to cells which express the epidermal growth factor receptor (EGFR). The recombinant Ad5 contained a wild-type L5 gene (which encodes the fiber and its tropism determinants) in tandem with an engineered L5 sequence which encoded a short biotin acceptor peptide (BAP) sequence inserted within the L5 gene. The resulting recombinant chimeric adenovirus expressed both wild type fibers and recombinant fibers in which the BAP was biotinylated by a cellular biotin ligase, resulting in an Ad5 recombinant with a biotin "scaffold" exposed upon its exterior. The authors then added an epidermal growth factor (EGF) peptide conjugated to avidin, which bound to both the biotinylated virus (at the avidin) and the EGFR-expressing target cells (at the EGF) [72]. A generic example of the scaffolding approach is shown in Figure 4.

The scaffold approach to viral retargeting is convenient because it allows any biotinylated virus to be retargeted towards any cell type for which the experimenter can adduct avidin to some ligand whose receptor is displayed by the target cell population. It is also convenient in that the recombinant Ad5 carries all the information necessary to reproduce itself within its genome with no further input from the experimenter. However, the functionalized adaptor molecule (the EGF-avidin in this example) must be continually supplied for the tropism toward EGFR-expressing cells to be maintained.

The alphaherpesvirus HSV-1 is an important human pathogen, and it has been extensively utilized for the creation of RCOVs [73]. Because the entry requirements of HSV-1 have been well-characterized [74] it is an attractive candidate for rational retargeting approaches. The alphaherpesviruses encode four envelope glycoproteins necessary and sufficient for virion binding and entry into a host cell, of which the glycoprotein D (gD) is the major determinant of HSV tropism [75] [76]. The most important cognate binding partners for the HSV-1 gD are nectins 1 and 2, both of which are immunoglobulin-like cell-cell adhesion proteins [74] [77]. Because nectins are present on many cell types, including and especially peripheral neurons [78], the alphaherpesviruses display a very broad host tropism and a pronounced neurotropism [77] [78].

Nakano and colleagues were the first to demonstrate HSV-1 retargeting through the use of a soluble adapter molecule. The adaptor they used had two binding specificities (a "bi-specific" adaptor), separated by a short peptide spacer. One arm of the adaptor was a single-chain antibody (scFv) which bound the EGFR, while the other arm contained the native binding site of the HSV-1 gD, the variable domain of the nectin-1 peptide. The authors demonstrated that in the presence of the adaptor, HSV-1 infection of cells expressing the EGFR was nearly as efficient as infection of nectin-1-expressing cells in the absence of the adaptor [79].

Unlike the scaffold approach to viral retargeting, the use of bi-specific adaptor molecules requires no detailed knowledge of the ligands at the viral surface since they can be treated as any other epitope(s) against which monoclonal antibodies can be easily raised. 


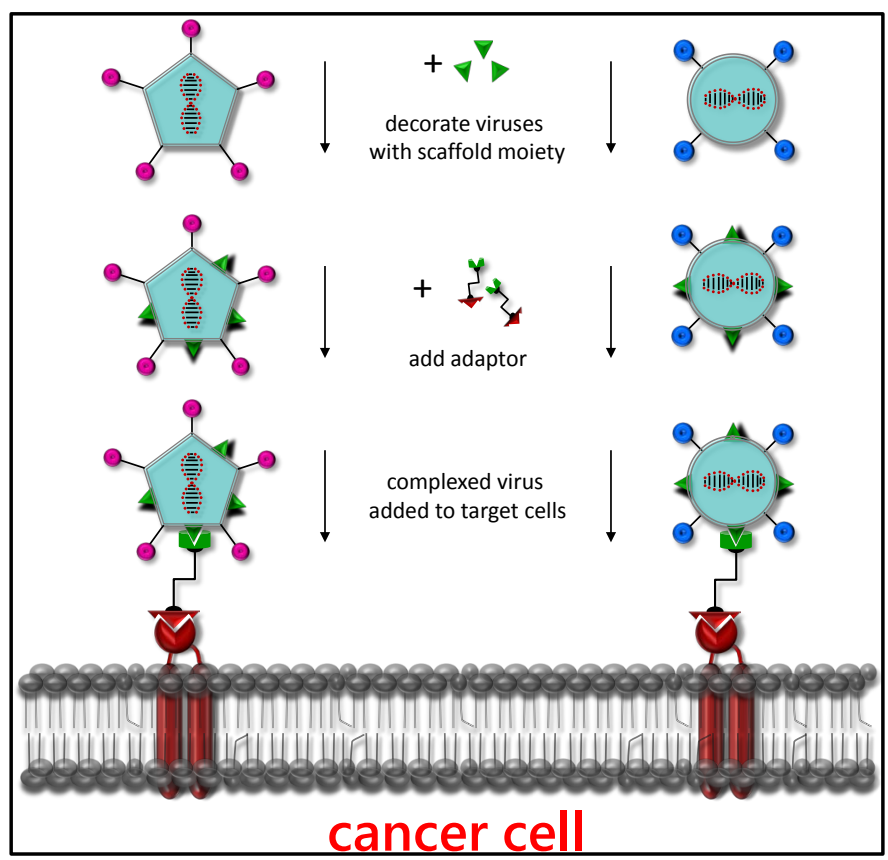

Figure 4. Scaffolding. A virus with its native receptor binding ligands (pink) is retargeted to cells with a cancer-specific cell-surface receptor (red with red pie-shaped antigen). The virus is first decorated with a scaffold molecule (green triangle). This decoration can be through either chemical or genetic means (see text). The scaffolded virus now interacts with an adaptor molecule which has one binding specificity for the scaffold and the other for the cancer-specific cell surface receptor. Any virus may be retargeted toward the cancer-specific cell surface receptor without changing the scaffold molecule.

\section{Transcriptional Restriction}

Rather than restricting the entry of a therapeutic virus to only certain cell types, it is possible to restrict the replication of a virus to a specific, targeted cell type by placing a viral gene product which is essential for viral replication under the control of a tissue-specific promoter. This approach is known as "transcriptional restriction" or "transcription targeting," and it relies upon promoters which occur only in certain tissues or which occur only in cancerous cells. The former are referred to as "tissue-specific" promoters, while the latter are referred to as "cancer-specific" or "pan-cancer" promoters.

Promoters are specific and continuous DNA sequences which bind transcription factors and other proteins necessary for transcription [25]. Promoter DNA segments can be used to engineer selectivity into RCOVs, a practice known as "transcriptional targeting," "transcriptional restriction” or "transcriptional control." Genes critical for viral replication are placed under the control of tissue- or cancer-specific promoter sequences, limiting replication of a therapeutic virus to cases in which that one critical component is successfully expressed. It is important to note that this particular strategy has been demonstrated only in viruses where the viral genome is replicated within the host cell nucleus. Viruses which replicate within the cytoplasmic compartment encode their own transcription factors and in any case would not come into contact with host transcription factors [80].

The existence of tissue-specific transcription control elements was originally exploited to provide transcriptional selectivity to viral vectors used for gene therapy [81]-[83], but many RCOVs with replication-critical genes driven by tissue-specific or cancer-specific promoters have been demonstrated [84]-[87].

The adenoviruses are by far the most often-modified virus type for transcriptional targeting. This is in part because the adenovirus genome is well-characterized and easy to manipulate. The adenovirus E1A gene acts to permit transcription of early genes within the host cell environment, and as such expression of this gene is necessary for efficient viral replication [88]. Placing the E1A gene under the regulation of various non-viral tissue- 
or tumor-specific promoters to limit its replication to a desired tissue or cell type is by now a common strategy [88] [89]. The advantage of this approach is obvious-besides the added selectivity provided by the tissue- or cancer-specific promoter, one need only change the promoter to change the cellular/tissue replication profile of the oncolytic adenovirus. Other non-adenovirus OVs have also been transcriptionally-regulated using tissue- or tumor-specific promoters with some success, including the herpesviruses [90] [91], and the retroviruses [92].

The first transcriptionally-regulated RCOV was an adenovirus genetically engineered such that portions of the androgen-responsive prostate-specific antigen (PSA) promoter were used to drive expression of the adenovirus E1A gene [85]. The PSA is expressed in detectable amounts usually only in non-cancerous epithelial cells of the prostate [93], but is often expressed in prostate tumors arising from the same tissue [94]. The recombinant virus (an adenovirus serotype 5 designated CN706 and later known variously as CV706 and CG7060) used a prostate-specific enhancer/promoter sequence combination to drive expression of the replication-critical E1A gene, thereby limiting viral replication to cells containing the PSA transcription control elements. It has been demonstrated that LNCaP cells (which express PSA) produced a CN706 titer much higher than prostate-derived cells which do not express PSA [85]. This virus has progressed to phase I/II clinical trials in humans against metastatic prostate cancer [95].

Promoters can also be cancer-specific (sometimes referred to as “pan-cancer” promoters). An example of a pan-cancer promoter is the human telomerase reverse transcriptase (hTERT) promoter, which drives expression of the catalytic subunit of the eukaryotic telomerase enzyme [25] [96] [97]. See the discussion of the hTERT in CRC and CRC-derived cell lines (below).

\section{Translational Restriction}

Cancerous cells differ from normal adult somatic cells in that they often inappropriately express (or overexpress) telomerase, vascular endothelial growth factor (VEGF), growth factors such as epidermal growth factor (EGF) and fibroblast growth factor (FGF), matrix metalloproteinases and other peptides which increase their potential for dysregulated growth, allow them to avoid apoptosis, and push the system toward neoplastic transformation [23]. One way in which cancerous cells accomplish this is through the overexpression of the eukaryotic initiation factor subunit 4E (eIF-4E or eIF4E) [98] [99]. The initiation of mRNA translation in eukaryotes is a complex process [100]. For the present it is sufficient to identify the eIF-4F subunit as one member of a larger molecular complex known as eIF-4F whose purpose is to position the ribosome on the mRNA for the first phase of translation, and is a necessary component of the 43S translation pre-initiation complex [101]. A critical point is that the binding of the eIF-4E subunit to the pre-initiation complex is the rate-limiting step of translation initiation [102]. When eIF-4F is present in limiting quantities, mRNAs with very long 5'-UTRs or 5'-UTRs with CG-rich, complex two-dimensional structures will be translated with a lower efficiency (and result in less expressed protein product) than will transcripts with short 5'-UTRs [98] [101]. When the eIF-4E is overexpressed, even those mRNA transcripts with long or complex 5'-UTRs will be translated at a rate comparable to the simpler transcripts. This is significant because many of the gene products associated with the cancerous or transformed phenotype are encoded with long, GC-rich 5'-UTRs which tend to form complex secondary structures [101]. Many transformed cells and cancers, including CRC, overexpress eIF-4E [98] [99] [103]. Overexpression of eIF-4E is by itself sufficient to induce a transformed phenotype in many cell types, and for this reason it is properly described as a proto-oncogene [104]. Taken together, the tendency of cancer cells to overexpress eIF-4E and their resulting ability to efficiently translate transformation-associated proteins with long or complex 5'-UTRs form the basis of a kind of translational control which can be utilized to restrict the expression of replication-critical viral mRNAs to cells which overexpress the eIF-4E. While not nearly as utilized as transcriptional restriction of oncolytic viral replication, the strategy of limiting the expression of proteins critical for viral replication through the use of complex 5'-UTRs has been utilized with some success in several different RCOV types.

A recent example provided by Lee and colleagues [105] not only demonstrates successful translational regulation in a RCOV but also shows how regulatory regimes can be designed which interact synergistically and produce greater oncolytic selectivity than would be possible with just a single regulatory constraint. The HSV-1 gene ICP27 is essential for viral replication [106]. Lee and colleagues [105] have engineered a recombinant HSV-1 in which the ICP27 gene was placed under both transcriptional and translational control. A modified promoter (designated ARR2PB) for the prostate-specific protein probasin [107] was used to drive expression of 
ICP27 in the recombinant HSV-1. The ICP27 gene construct was further modified by the insertion of the fibroblast growth factor-2 (FGF-2) 5'-UTR upstream of the ICP27 ORF. The FGF-2 gene is encoded with a UTR which is long, structurally complex and GC-rich, and the resulting secondary structure can only be unwound efficiently in the presence of large amounts of the eIF-4E/eIF-4F complex [101] [108]. To further restrict viral replication, the entire promoter-5'UTR construct was inserted into the position within the HSV-1 genome usually occupied by the viral $T K$ gene, thereby deleting it. The resulting recombinant virus, designated ARR2PB-ICP27, showed reduced toxicity in vivo and significantly greater oncolytic activity than either the wild type virus or the virus in which the ICP27 gene was under transcriptional regulation only [105].

\section{Pan-Cancer Biomarkers Can Be Used to Enhance Oncoselectivity in RCOVs}

We will briefly review the expression of two pan-cancer biomarkers, both of which are frequently expressed as part of a tumor cell's proliferation strategy: hTERT, the enzymatic subunit of the telomerase, and survivin, an anti-apoptotic protein. Both are widely expressed at high levels in many malignancies, both have become important therapeutic targets, and both have been successfully exploited for transcriptional regulation of RCOVs.

\subsection{Survivin and Its Promoter}

Survivin is a 142 -amino acid $(16.5 \mathrm{kDa})$ protein, the smallest and simplest member of the inhibitor of apoptosis (IAP) family of proteins [109] [110]. In humans, survivin is encoded by the BIRC5 (baculoviral inhibitor of apoptosis repeat-containing 5) gene, and is highly expressed in most human cancers but also in fetal tissues and tissues with very high mitotic indices [111]-[113]. The expression of survivin by tumor cells is also associated with poorer prognosis and shorter survival times in CRC patients [114]-[116]. Indeed, a meta-analysis of 11 clinical trials involving CRC patients has established a significant correlation between tumor survivin expression and lymph node metastasis, blood vessel invasion, and generally poorer prognosis [115].

Survivin expression may be exploited to endow RCOVs with a degree of oncoselectivity. A previously-characterized truncated survivin promoter [117] was employed by Kamizono and co-workers to regulate the expression of the adenovirus replication-essential E1A gene [118]. The resulting recombinant adenovirus showed improved selectivity for cancer cells in vitro and statistically significant inhibition of xenograft-derived tumors in a nude mouse model when compared to an adenovirus which was merely deleted for the E1A region [118]. Many other examples exist in which the survivin promoter has been used to enhance the oncoselectivity of adenoviruses [119]-[121]. To our knowledge no examples presently exist in which the survivin promoter has been used to improve oncoselectivity through transcriptional targeting in any RCOVs except the adenoviruses.

\subsection{The hTERT Promoter}

Cancerous cells are immortal in part because of the inappropriate expression of human telomerase, an enzyme which adds short tandem DNA repeats to the 3' end of eukaryotic chromosomes, thereby overcoming the "end-replication problem" on the lagging strand [122]. The hTERT is the catalytic subunit of the telomerase ribonucleoprotein [123]. Because the hTERT is not usually expressed in significant amounts in normal, post-mitotic, non-stem adult cells but is highly expressed in nearly all cancerous cells hTERT activity is an important pan-cancer marker and therapeutic target [97] [124]-[126]. In cancer cells in general, and in CRC in particular, hTERT expression is thought to be essential for disease progression and levels of hTERT expression have been observed to rise with tumor maturation [126] [127].

Transcription of hTERT is driven by the hTERT promoter, which is highly complex and not completely characterized [123] [127]. The promoter core is approximately $250 \mathrm{bp}$ in length and contains binding sites for both stimulatory and inhibitory transcription factors. Activators of transcription (directly by promoter binding or indirectly) include Cyclins D and E, members of the c-MYC family, the EGF (via the Ras/MEK/ERK pathway), Specificity Protein 1 (Sp1), Activating Enhancer-binding Protein-2 (AP-2), estrogen, and others [128]-[131].

The hTERT promoter has been used extensively as a cancer-specific transcriptional regulator of viral replication in oncolytic virus design [25]. One such example is a recombinant adenovirus designated Adv-TERTp-E1A described by Huang and co-workers [132]. The recombinant Adv-TERTp-E1A used a 454-bp region of the hTERT promoter to drive expression of the adenovirus E1A gene. The authors demonstrated that this construct replicated at nearly wild-type levels in hTERT-positive cell lines such as A549 and Hep3b, but replicated ap- 
proximately 200-fold less efficiently in hTERT-negative cell lines. When tested in a nude mouse xenograft model using tumors produced by subcutaneous injection of Heb3b cells, the Adv-TERTp-E1A virus replicated to high titers within the tumor mass and caused tumor necrosis and mass reduction when compared to the controls [132]. Another example of the successful use of the hTERT promoter to engineer RCOV oncoselectivity is the adenovirus designated OBP-301, commercialized by Oncolys BioPharma under the name Telomelysin. OBP-301 is a adenovirus (serotype 5) in which expression of both the E1A and E1B genes was put under the control of the hTERT promoter [133] [134]. After demonstrating significant reductions in tumors developed in nude mice xenografted with a human lung tumor cell line, phase I trials showed some durable tumor reductions in approximately half of treated patients [135]. Many other examples of this strategy exist [25].

\section{CRC Specific Biomarkers Can Also Be Used to Enhance Oncoselectivity in RCOVs}

There are a number of biomarkers which are somewhat specific for hCRC, and have obvious utility in the design of virotherapeutic agents targeted specifically to CRC. Some of the most promising are detailed below.

\subsection{Activating Mutations in K-ras}

The KRAS gene encodes the KRAS GTPase, (also known as Kirsten-ras, Ki-ras and C-KI-RAS2), a small, membrane-bound G-protein and proto-oncogene which is part of the epidermal growth factor receptor (EGFR) transduction cascade [136] [137]. KRAS is activated when bound to GTP, which is (under normal conditions) converted to GDP by the removal of the $\gamma$ (terminal) phosphate, returning the KRAS GTPase to its inactive state [138]. KRAS mutants can be constitutively active, resulting in continuous signal transduction through its downstream effector components and, ultimately, cellular survival, growth and proliferation uncoupled from EGFR activation [138]-[140]. The KRAS gene is mutated in approximately 40\% of CRC lesions [141]-[143]. Although KRAS mutations can also occur in other cancer types (e.g., lung adenocarcinomas) [144], they have been studied most frequently in the context of CRC.

Reoviruses are among the viral families sometimes referred to as "naturally oncolytic" [145] [146]. Although the reoviruses do not usually cause clinically significant human disease, these viruses are able to replicate in human cells which exhibit constitutive activation of the RAS pathway. This is because RAS (and KRAS) overexpression prevents the phosphorylation of the protein kinase R (PKR) cellular defense kinase, which in turn prevents cytoplasmic degradation of the reovirus double-stranded RNA [147] [148]. Reolysin (Oncolytics Biotech), a wild-type, replication-competent reovirus [149] has been tested in clinical trials against metastatic melanoma in a phase II clinical trial [150] with follow-on trials against metastatic CRC currently in the recruitment stage (trials NCT01274624 and NCT01622543, www.ClinicalTrials.gov).

\subsection{Wnt Signaling Dysregulation, Adenomatous Polyposis Coli (APC) Mutation, and $\beta$-Catenin Accumulation}

Dysregulation of the Wnt signaling cascade is one of the defining characteristics of CRC [151], and perhaps 90\% of colorectal carcinomas exhibit inappropriate Wnt/ $\beta$-catenin pathway activation [152]. The canonical Wnt oncogene signaling pathway and its importance in CRC has been extensively reviewed [153]-[155]. In normal somatic cells, the phosphorylation of $\beta$-catenin by the serine/threonine kinases casein kinase 1 (CK1) and glycogen synthase kinase $3 \beta$ (GSK $3 \beta$ ) trigger its ubiquitination and subsequent destruction in the proteasome [156]. Phosphorylation of $\beta$-catenin occurs when the molecule is complexed with the adenomatous polyposis coli (APC)/axin1 "destruction complex" [155] [157] [158]. In many CRC tumor cells dysregulated Wnt signaling arising from mutations or truncations in APC results in the inhibition of phosphorylation and subsequent destruction of $\beta$-catenin, which contributes to the cytoplasmic accumulation of $\beta$-catenin in a "stabilized" state [159]. Stabilized $\beta$-catenin is imported into the nucleus where it binds to members of the Tcf/Lef family of transcription factors, changing them from transcriptional repressors to transcriptional activators which bind to Tcf/Lef target gene Wnt response elements (WREs) [160] and begin an inappropriate and oncogenic program of transcription [161]. The precise contribution of APC to this process is not yet completely understood [156], but the importance of defective APC to the development of CRC is demonstrated by the observation that individuals harboring mutations in the APC gene almost always exhibit some form of the familial adenomatous polyposis (FAP) phenotype [162] [163]. Dysregulated Wnt signaling provides an opportunity to increase oncoselectivity in 
RCOVs, and has been heavily exploited in the adenoviruses, with additional work done in both the herpesviruses and the parvoviruses.

Numerous examples exist in which the regulatory elements which drive the expression of the Tcf/Lef genes (inappropriately activated in CRC and other cancers) have been used in recombinant adenoviruses to drive replication-critical genes and produce transcriptionally-targeted RCOVs which preferentially replicate in cells with dysregulated Wnt signaling [164]-[166]. An example from Toth and colleagues [165] is illustrative. The recombinant adenovirus VRX-009 was made by replacement of the native Ad5 viral promoter driving expression of the viral E4 gene with a synthetic promoter containing five Tcf binding sequences and a native TATA box sequence. It has been demonstrated that the resulting recombinant adenovirus expressed the Ad5 protein E4ORF3 (indicating successful replication) at levels which were in some cases nearly equal to wild-type adenoviruses in the CRC cell lines SW480 and LS513 (with active Tcf/Lef promoters). In the non-CRC cell lines A549 and DU145 (breast and prostate carcinomas, respectively, with inactive Tcf/Lef promoters) very little or no E4ORF3 expression was observed, indicating that the recombinant VRX-009 has achieved some degree of selectivity for cells with strong $\beta$-catenin stabilization and activation of the Tcf/Lef transcriptional program [165].

Use of the Tcf/Lef promoter to achieve oncoselectivity has also been demonstrated in the herpesviruses (i.e., HSV-1) and the parvoviruses. Kuroda and colleagues [167] constructed several synthetic $\beta$-catenin-Tcf/Lef promoters and tested their ability to drive expression of the HSV-1 ICP4 protein in cells with activated Wnt pathways. They found that expression of the ICP4 gene was most efficiently driven by a synthetic promoter composed of 12 Tcf-responsive element sequences augmented with a single transcription enhancer element (derived from a human gene). The recombinant HSV-1 was able to selectively kill cells with strong $\beta$-catenin/Tcf activation (SW480, HepG2 and LS1034 cells), but replicated poorly in cancerous cells devoid of $\beta$-catenin/Tcf activation (LoVo, HT29 and A549 cells). In agreement with these data, the HSV-1 recombinant was able to markedly regress tumor xenografts in nude mice when the tumors were derived from SW480, but had no significant effect upon tumors derived from A549 in the same system [167].

\section{Conclusions and Future Challenges}

A number of RCOVs have been used in human clinical trials, including viruses from the Adenoviridae, Herpesviridae, Parvoviridae, Poxviridae, Paramyxoviridae, Picornaviridae, Reoviridae and Rhabdoviridae families [168]. Thus far, the adverse effects of RCOV administration seem to relatively mild and tolerable when compared to the undesirable effects of cancer chemotherapy and radiotherapy. An example of a clinically-trialed RCOV is SillaJen's JX-594 (Pexa-Vec, originally developed by Jennerex Biotherapeutics), a VACV-based RCOV which recently completed a phase II clinical study (30 patients) in patients with advanced hepatocellular carcinoma. In this study a high-dose group was compared to a low-dose group. The high dose group exhibited a significantly longer median survival time (14.1 months) than did the low-dose group (6.7 months) [169]. This dramatic increase in median survival time qualifies JX-594 as one of the most successful RCOVs to date in the clinic, and at the same time points out how much remains to be done.

This review has provided examples and explanations of some of the approaches used to improve or achieve oncoselectivity in RCOVs. As the field matures RCOVs will continue to grow in importance as new strategies for the enhancement of oncospecificity and oncolethality are developed. For example, the current drive to identify markers of cancer stem cells (CSCs) and tumor-initiating cells (TICs) [170] and improvements in our understanding of what constitutes stemness in CRC cells [171] [172] will ultimately lead to the identification of new targets for oncoselectivity in RCOVs targeted against CRC, as it has in RCOVs targeted against the TIC marker $\mathrm{CD}_{133^{+}}$[173]. Advances in delivery technologies [174] may enable delivery of RCOVs targeted against CRC directly to the mucinous environment of the colon, which has until this time presented a difficult barrier to delivery of therapeutic molecules. It should, however, also be emphasized that in the absence of virus-specific immune tolerance, an antigenically distinct panel of oncolytic viruses will be needed to successfully treat a specific cancer. A serial application of RCOVs could potentially eliminate residual tumors despite the virus-specific immune response.

It is our hope that a brief explanation of what has been done will stimulate the reader to imagine what could still be done using the same approaches in novel viruses, or what might be accomplished in CRCs using techniques which have until now been applied only to a small subset of other cancer types. Progress in the creation of new RCOVs will be evolutionary and revolutionary; both kinds will save lives and improve human health. 


\section{Acknowledgements}

Portions of this review were included in SJC's Ph.D. dissertation. We are grateful to James Sklut for reading this manuscript critically and providing technical assistance. Oncolytic virus studies in our lab are supported in part by an NIH grant (1R15CA156262-01) and a WMU-FRACCA grant to KE.

\section{References}

[1] Brenner, H., Kloor, M. and Pox, C.P. (2014) Colorectal Cancer. The Lancet, 383, 1490-1502. http://dx.doi.org/10.1016/S0140-6736(13)61649-9

[2] Siegel, R., Desantis, C. and Jemal, A. (2014) Colorectal Cancer Statistics, 2014. CA: A Cancer Journal for Clinicians, 64, 104-117. http://dx.doi.org/10.3322/caac.21220

[3] Taylor, I. (1996) Liver Metastases from Colorectal Cancer: Lessons from Past and Present Clinical Studies. The British Journal of Surgery, 83, 456-460. http://dx.doi.org/10.1002/bjs.1800830406

[4] American Cancer Society (2014) Colorectal Cancer Facts \& Figures 2014-2016. American Cancer Society, Atlanta.

[5] Langan, R.C., Mullinax, J.E., Raiji, M.T., Upham, T., Summers, T., Stojadinovic, A. and Avital, I. (2013) Colorectal Cancer Biomarkers and the Potential Role of Cancer Stem Cells. Journal of Cancer, 4, 241-250. http://dx.doi.org/10.7150/jca.5832

[6] DeVita, V.T. and Chu, E. (2008) A History of Cancer Chemotherapy. Cancer Research, 68, 8643-8653. http://dx.doi.org/10.1158/0008-5472.CAN-07-6611

[7] Shawver, L.K., Slamon, D. and Ullrich, A. (2002) Smart Drugs: Tyrosine Kinase Inhibitors in Cancer Therapy. Cancer Cell, 1, 117-123. http://dx.doi.org/10.1016/S1535-6108(02)00039-9

[8] Weiner, L., Surana, R. and Wang, S. (2010) Monoclonal Antibodies: Versatile Platforms for Cancer Immunotherapy. Nature Reviews Immunology, 10, 317-327. http://dx.doi.org/10.1038/nri2744

[9] Cross, D. and Burmester, J.K. (2006) Gene Therapy for Cancer Treatment: Past, Present and Future. Clinical Medicine \& Research, 4, 218-227. http://dx.doi.org/10.3121/cmr.4.3.218

[10] Hergt, R., Dutz, S., Müller, R. and Zeisberger, M. (2006) Magnetic Particle Hyperthermia: Nanoparticle Magnetism and Materials Development for Cancer Therapy. Journal of Physics: Condensed Matter, 18, S2919-S2934. http://dx.doi.org/10.1088/0953-8984/18/38/S26

[11] Wang, A., Langer, R. and Farokhzad, O. (2012) Nanoparticle Delivery of Cancer Drugs. Annual Review of Medicine, 63, 185-198. http://dx.doi.org/10.1146/annurev-med-040210-162544

[12] Brown, S., Brown, E. and Walker, I. (2004) The Present and Future Role of Photodynamic Therapy in Cancer Treatment. The Lancet Oncology, 5, 497-508. http://dx.doi.org/10.1016/S1470-2045(04)01529-3

[13] Fischer, K., Gedroyc, W. and Jolesz, F.A. (2010) Focused Ultrasound as a Local Therapy for Liver Cancer. The Cancer Journal, 16, 118-124. http://dx.doi.org/10.1097/PPO.0b013e3181db7c32

[14] Lukianova-Hleb, E.Y., Ren, X., Sawant, R.R., Wu, X., Torchilin, V.P. and Lapotko, D.O. (2014) On-Demand Intracellular Amplification of Chemoradiation with Cancer-Specific Plasmonic Nanobubbles. Nature Medicine, 20, 778784.

[15] Sinkovics, J.G. and Horvath, J.C. (2008) Natural and Genetically Engineered Viral Agents for Oncolysis and Gene Therapy of Human Cancers. Archivum Immunologiae et Therapiae Experimentalis, 56, 1-59. http://dx.doi.org/10.1007/s00005-008-0047-9

[16] Martuza, R.L., Malick, A., Markert, J.M., Ruffner, K.L. and Coen, D.M. (1991) Experimental Therapy of Human Glioma by Means of a Genetically Engineered Virus Mutant. Science, 252, 854-856. http://dx.doi.org/10.1126/science.1851332

[17] Garber, K. (2006) China Approves World's First Oncolytic Virus Therapy for Cancer Treatment. Journal of the National Cancer Institute, 98, 298-300. http://dx.doi.org/10.1093/jnci/dji111

[18] Hirsch, J. (2006) An Anniversary for Cancer Chemotherapy. JAMA, 296, 1518-1520. http://dx.doi.org/10.1001/jama.296.12.1518

[19] Middleton, M. and Margison, G. (2003) Improvement of Chemotherapy Efficacy by Inactivation of a DNA-Repair Pathway. The Lancet Oncology, 4, 37-44. http://dx.doi.org/10.1016/S1470-2045(03)00959-8

[20] Leoni, L. Bailey, B., Reifert, J., Bendall, H.H., Zeller, R.W., Corbeil, J., Elliot, G. and Niemeyer, C.C. (2008) Bendamustine (Treanda) Displays a Distinct Pattern of Cytotoxicity and Unique Mechanistic Features Compared with Other Alkylating Agents. Clinical Cancer Research, 14, 309-317.

[21] Lawley, P.D. and Phillips, D.H. (1996) DNA Adducts from Chemotherapeutic Agents. Mutation Research, 355, $13-40$. 
http://dx.doi.org/10.1016/0027-5107(96)00020-6

[22] Kelly, E. and Russell, S.J. (2007) History of Oncolytic Viruses: Genesis to Genetic Engineering. Molecular Therapy, 15, 651-659.

[23] Hanahan, D. and Weinberg, R.A. (2011) Hallmarks of Cancer: The Next Generation. Cell, 144, 646-674. http://dx.doi.org/10.1016/j.cell.2011.02.013

[24] Wollmann, G., Ozduman, K. and van den Pol, A.N. (2012) Oncolytic Virus Therapy of Glioblastoma Multiforme: Concepts and Candidates. Cancer Journal, 18, 69-81. http://dx.doi.org/10.1097/PPO.0b013e31824671c9

[25] Dorer, D. and Nettelbeck, D. (2009) Targeting Cancer by Transcriptional Control in Cancer Gene Therapy and Viral Oncolysis. Advanced Drug Delivery Reviews, 61, 554-571. http://dx.doi.org/10.1016/j.addr.2009.03.013

[26] Hemminki, O., Diaconu, I., Cerullo, V., Pesonen, S.K., Kanerva, A., Joensuu, T., Kairemo, K., Laasonen, L., Partanen, K., Kangasniemi, L., Lieber, A., Pesonen, S. and Hemminki, A. (2012) Ad3-hTERT-E1A, a Fully Serotype 3 Oncolytic Adenovirus, in Patients with Chemotherapy Refractory Cancer. Molecular Therapy, 20, 1821-1830. http://dx.doi.org/10.1038/mt.2012.115

[27] He, T.-C., Zhou, S., Da Costa, L.T., Yu, J., Kinzler, K.W. and Vogelstein, V. (1998) A Simplified System for Generating Recombinant Adenoviruses. Proceedings of the National Academy of Sciences of the United States of America, 95, 2509-2514. http://dx.doi.org/10.1073/pnas.95.5.2509

[28] Ginsberg, H.S. (1999) The Life and Times of Adenoviruses. Advances in Virus Research, 54, 1-13. http://dx.doi.org/10.1016/S0065-3527(08)60363-2

[29] Katsafanas G.C. and Moss, B. (2007) Colocalization of Transcription and Translation within Cytoplasmic Poxvirus Factories Coordinates Viral Expression and Subjugates Host Functions. Cell Host \& Microbe, 2, 221-228. http://dx.doi.org/10.1016/j.chom.2007.08.005

[30] Moss, B. (2012) Poxvirus Cell Entry: How Many Proteins Does It Take? Viruses, 4, 688-707. http://dx.doi.org/10.3390/v4050688

[31] Parato, K., Breitbach, C., Le Boeuf, F., Wang, J., Storbeck, C., Ilkow, C., Diallo, J.-S., Falls, T., Burns, J., Garcia, V., Kanji, F., Evgin, L., Hu, K., Paradis, F., Knowles, S., Hwang, T.-H., Vanderhyden, B., Auer, R., Kirn, D. and Bell, J. (2012) The Oncolytic Poxvirus JX-594 Selectively Replicates in and Destroys Cancer Cells Driven by Genetic Pathways Commonly Activated in Cancers. Molecular Therapy, 20, 749-758. http://dx.doi.org/10.1038/mt.2011.276

[32] Traut, T.W. (1994) Physiological Concentrations of Purines and Pyrimidines. Molecular and Cellular Biochemistry, 140, 1-22. http://dx.doi.org/10.1007/BF00928361

[33] Alegre, M.M., Robison, R.A. and O’Neill, K.L. (2012) Thymidine Kinase 1 Upregulation Is an Early Event in Breast Tumor Formation. Journal of Oncology, 2012, Article ID: 575647.

[34] Mastrangelo M.J., Maguire, H.C., Eisenlohr, L.C., Laughlin, C.E., Monken, C.E., McCue, P.A., Kovatich, A.J. and Lattime, E.C. (1999) Intratumoral Recombinant GM-CSF-Encoding Virus as Gene Therapy in Patients with Cutaneous Melanoma. Cancer Gene Therapy, 6, 409-422. http://dx.doi.org/10.1038/sj.cgt.7700066

[35] Park, B.H., Hwang, T., Liu, T.C., Sze, D.Y., Kim, J.S., Kwon, H.C., Oh, S.Y., Han, S.Y., Yoon, J.H., Hong, S.H., Moon, A., Speth, K., Park, C., Ahn, Y.J., Daneshmand, M., Rhee, B.G., Pinedo, H. and Bell, J.C. (2008) Use of a Targeted Oncolytic Poxvirus, JX-594, in Patients with Refractory Primary or Metastatic Liver Cancer: A Phase I Trial. The Lancet Oncology, 9, 533-542. http://dx.doi.org/10.1016/S1470-2045(08)70107-4

[36] Marsh, M. and Helenius, A. (2006) Virus Entry: Open Sesame. Cell, 124, 729-740. http://dx.doi.org/10.1016/j.cell.2006.02.007

[37] Smith, A.E. and Helenius, A. (2004) How Viruses Enter Animal Cells. Science, 304, 237-241. http://dx.doi.org/10.1126/science.1094823

[38] Leja, J., Nilsson, B., Yu, D., Gustafson, E., Åkerström, G., Öberg, K., Giandomenico, V. and Essand, M. (2010) DoubleDetargeted Oncolytic Adenovirus Shows Replication Arrest in Liver Cells and Retains Neuroendocrine Cell Killing Ability. PLoS ONE, 5, e8916. http://dx.doi.org/10.1371/journal.pone.0008916

[39] Kreppel, F. and Kochanek, S. (2008) Modification of Adenovirus Gene Transfer Vectors with Synthetic Polymers: A Scientific Review and Technical Guide. Molecular Therapy, 16, 16-29. http://dx.doi.org/10.1038/sj.mt.6300321

[40] Fisher, K.D. and Seymour, L.W. (2010) HPMA Copolymers for Masking and Retargeting of Therapeutic Viruses. Advanced Drug Delivery Reviews, 62, 240-245. http://dx.doi.org/10.1016/j.addr.2009.12.003

[41] Green, N.K., Morrison, J., Hale, S., Briggs, S.S., Stevenson, M., Subr, V., Ulbrich, K., Chandler, L., Mautner, V., Seymour, L.W. and Fisher, K.D. (2008) Retargeting Polymer-Coated Adenovirus to the FGF Receptor Allows Productive Infection and Mediates Efficacy in a Peritoneal Model of Human Ovarian Cancer. The Journal of Gene Medicine, 10, 280-289. http://dx.doi.org/10.1002/jgm.1121

[42] Singh, R., Tian, B. and Kostarelos, K. (2008) Artificial Envelopment of Nonenveloped Viruses: Enhancing Adenovirus 
Tumor Targeting in Vivo. The FASEB Journal, 22, 3389-3402. http://dx.doi.org/10.1096/fj.08-103275

[43] Fishburn, C.S. (2008) The Pharmacology of PEGylation: Balancing PD with PK to Generate Novel Therapeutics. The Journal of Pharmaceutical Sciences, 10, 4167-4183. http://dx.doi.org/10.1002/jps.21278

[44] Kim, P.H., Sohn, J.-H., Choi, J.-W., Jung, Y., Kim, S.W., Haam, S. and Yun, C.-O. (2011) Active Targeting and Safety Profile of PEG-Modified Adenovirus Conjugated with Herceptin. Biomaterials, 32, 2314-2326. http://dx.doi.org/10.1016/j.biomaterials.2010.10.031

[45] Miest, T.S. and Cattaneo, R. (2014) New Viruses for Cancer Therapy: Meeting Clinical Needs. Nature Reviews Microbiology, 12, 23-34. http://dx.doi.org/10.1038/nrmicro3140

[46] Waehler, R., Russell, S.J. and Curiel, D.T. (2007) Engineering Targeted Viral Vectors for Gene Therapy. Nature Reviews Genetics, 8, 573-587. http://dx.doi.org/10.1038/nrg2141

[47] Shayakhmetov, D.M., Li, Z.Y., Ni, S. and Lieber, A. (2004) Analysis of Adenovirus Sequestration in the Liver, Transduction of Hepatic Cells, and Innate Toxicity after Injection of Fiber-Modified Vectors. Journal of Virology, 78, 5368-5381. http://dx.doi.org/10.1128/JVI.78.10.5368-5381.2004

[48] Doronin, K., Shashkova, E.V., May, S.M., Hofherr, S.E. and Barry, M.A. (2009). Chemical Modification with High Molecular Weight Polyethylene Glycol Reduces Transduction of Hepatocytes and Increases Efficacy of Intravenously Delivered Oncolytic Adenovirus. Human Gene Therapy, 20, 975-988. http://dx.doi.org/10.1089/hum.2009.028

[49] Alemany, R., Suzuki, K. and Curiel, D.T. (2000) Blood Clearance Rates of Adenovirus Type 5 in Mice. The Journal of General Virology, 81, 2605-2609.

[50] Küster, K., Koschel, A., Rohwer, N., Fischer, A., Weidenmann, B. and Anders, M. (2010) Downregulation of the Coxsackie and Adenovirus Receptor in Cancer Cells by Hypoxia Depends on HIF-1alpha. Cancer Gene Therapy, 17, 141146. http://dx.doi.org/10.1038/cgt.2009.49

[51] Kim, M., Zinn, K.R., Barnett, B.G., Sumerel, L.A., Krasnykh, V., Curiel, D.T. and Douglas, J.T. (2002) The Therapeutic Efficacy of Adenoviral Vectors for Cancer Gene Therapy Is Limited by a Low Level of Primary Adenovirus Receptors on Tumour Cells. European Journal of Cancer, 38, 1917-1926. http://dx.doi.org/10.1016/S0959-8049(02)00131-4

[52] Cronin, J., Zhang, X.-Y. and Reiser, J. (2005) Altering the Tropism of Lentiviral Vectors through Pseudotyping. Current Gene Therapy, 5, 387-398. http://dx.doi.org/10.2174/1566523054546224

[53] Kolokoltsov, A., Weaver, S. and Davey, R. (2004) Efficient Functional Pseudotyping of Oncoretroviral and Lentiviral Vectors by Venezuelan Equine Encephalitis Virus Envelope Proteins. Journal of Virology, 79, 756-763. http://dx.doi.org/10.1128/JVI.79.2.756-763.2005

[54] Mathis, J., Stoff-Khalili, M. and Curiel, D. (2005) Oncolytic Adenoviruses—Selective Retargeting to Tumor Cells. Oncogene, 24, 7775-7791. http://dx.doi.org/10.1038/sj.onc.1209044

[55] Laquerre, S., Anderson, D.B., Stolz, D.B. and Glorioso, J.C. (1998) Recombinant Herpes Simplex Virus Type 1 Engineered for Targeted Binding to Erythropoietin Receptor-Bearing Cells. Journal of Virology, 72, 9683-9697.

[56] Mizuguchi, H., Kay, M. and Hayakawa, T. (2001) Approaches for Generating Recombinant Adenovirus Vectors. Advanced Drug Delivery Reviews, 52, 165-176. http://dx.doi.org/10.1016/S0169-409X(01)00215-0

[57] Haviv, Y., Blackwell, J., Kanerva, A., Nagi, P., Krasnykh, V., Dmitriev, I., Wang, M., Naito, S., Lei, X., Hemminki, A., Carey, D. and Curiel, D.T. (2002) Adenoviral Gene Therapy for Renal Cancer Requires Retargeting to Alternative Cellular Receptors. Cancer Research, 62, 4273-4281.

[58] Haisma, H.J. and Geerts, L. (2010) Targeting Adenoviral Entry to Enhance Oncolytic Antitumor Response. Open Gene Therapy Journal, 3, 9-14. http://dx.doi.org/10.2174/1875037001003020009

[59] Whelan, S.P. and Wertz, G.W. (2002) Transcription and Replication Initiate at Separate Sites on the Vesicular Stomatitis Virus Genome. Proceedings of the National Academy of Sciences of the United States of America, 99, 9178-9183. http://dx.doi.org/10.1073/pnas.152155599

[60] Martinez, I., Rodriguez, L.L., Jimenez, C., Pauszek, S.J. and Wertz, G.W. (2003) Vesicular Stomatitis Virus Glycoprotein Is a Determinant of Pathogenesis in Swine, a Natural Host. Journal of Virology, 77, 8039-8047. http://dx.doi.org/10.1128/JVI.77.14.8039-8047.2003

[61] Letchworth, G.J., Rodriguez, L.L. and Del Cbarrera, J. (1999) Vesicular Stomatitis. The Veterinary Journal, 157, 239260. http://dx.doi.org/10.1053/tvjl.1998.0303

[62] Barber, G.N. (2004) Vesicular Stomatitis Virus as an Oncolytic Vector. Viral Immunology, 17, 516-527. http://dx.doi.org/10.1089/vim.2004.17.516

[63] Stojdl, D.F., Lichty, B.D., tenOver, B.R., Paterson, J.M., Power, A.T., Knowles, S., Marius, R., Reynard, J., Poliquin, L., Atkins, H., Brown, E.G., Durbin, R.K., Durbin, J.E., Hiscott, J. and Bell, J.C. (2003) VSV Strains with Defects in Their Ability to Shutdown Innate Immunity Are Potent Systemic Anti-Cancer Agents. Cancer Cell, 4, 263-275. 
http://dx.doi.org/10.1016/S1535-6108(03)00241-1

[64] Russell, S.J. (2002) RNA Viruses as Virotherapy Agents. Cancer Gene Therapy, 9, 961-966. http://dx.doi.org/10.1038/sj.cgt.7700535

[65] Hastie, E., Cataldi, M., Mariott, I. and Grdzelishvili, V.A. (2013) Understanding and Altering Cell Tropism of Vesicular Stomatitis Virus. Virus Research, 176, 16-32. http://dx.doi.org/10.1016/j.virusres.2013.06.003

[66] Kretzschmar, E., Buonocore, L., Schnell, M.J. and Rose, J.K. (1997) High-Efficiency Incorporation of Functional Influenza Virus Glycoproteins into Recombinant Vesicular Stomatitis Viruses. Journal of Virology, 71, 5982-5989.

[67] Finkelshtein, D., Werman, A., Novick, D., Barak, S. and Rubinstein, M. (2013) LDL Receptor and Its Family Members Serve as the Cellular Receptors for Vesicular Stomatitis Virus. Proceedings of the National Academy of Sciences of the United States of America, 110, 7306-7311. http://dx.doi.org/10.1073/pnas.1214441110

[68] Muik, A., Werbizki, J.I., Wilflingesder, D., Giroglou, T., Ebert. O., Kraft, A., Dietrich, U., Zimmer, G., Momma, S. and von Laer, D. (2011) Pseudotyping Vesicular Stomatitis Virus with Lymphocytic Choriomeningitis Virus Glycoproteins Enhances Infectivity for Glioma Cells and Minimizes Neurotropism. Journal of Virology, 85, 5679-5684. http://dx.doi.org/10.1128/JVI.02511-10

[69] Ayala-Breton, C., Barber, G.M., Russell, S.J. and Peng, K.W. (2012) Retargeting Vesicular Stomatitis Virus Using Measles Virus Envelope Glycoproteins. Human Gene Therapy, 23, 484-491. http://dx.doi.org/10.1089/hum.2011.146

[70] Holliger, P. and Hudson, P.J. (2005) Engineered Antibody Fragments and the Rise of Single Domains. Nature Biotechnology, 23, 1126-1136. http://dx.doi.org/10.1038/nbt1142

[71] Verheije M. and Rottier, P. (2012) Retargeting of Viruses to Generate Oncolytic Agents. Advances in Virology, 2012, Article ID: 798526.

[72] Pereboeva, L., Komarova, S., Roth, J., Ponnazhagan, S. and Curiel, D. (2007) Targeting EGFR with Metabolically Biotinylated Fiber-Mosaic Adenovirus. Gene Therapy, 14, 627-637. http://dx.doi.org/10.1038/sj.gt.3302916

[73] Shen, Y. and Nemunaitis, J. (2006) Herpes Simplex Virus 1 (HSV-1) for Cancer Treatment. Cancer Gene Therapy, 13, 975-992. http://dx.doi.org/10.1038/sj.cgt.7700946

[74] Karaba, A.H., Kopp, S.J. and Longnecker, R. (2011) Herpesvirus Entry Mediator and Nectin-1 Mediate Herpes Simplex Virus 1 Infection of the Murine Cornea. Journal of Virology, 85, 10041-10047. http://dx.doi.org/10.1128/JVI.05445-11

[75] Cuddington, B.P. and Mossman, K.L. (2014) Permissiveness of Human Cancer Cells to Oncolytic Bovine Herpesvirus 1 Is Mediated in Part by KRAS Activity. Journal of Virology, 88, 6885-6895. http://dx.doi.org/10.1128/JVI.00849-14

[76] Campadelli-Fiume, G., Amasio, M., Avitabile, E., Cerretani, A., Forghieri, C., Gianni, T. and Menotti, L. (2007) The Multipartite System That Mediates Entry of Herpes Simplex Virus into the Cell. Reviews in Medical Virology, 17, 313326. http://dx.doi.org/10.1002/rmv.546

[77] Di Giovine, P., Settembre, E.C., Bhargava, A.K., Luftig, M.A., Lou, H., Cohen, G.H., Eisenberg, R.J., Krummenacher, C. and Carfi, A. (2011) Structure of Herpes Simplex Virus Glycoprotein D Bound to the Human Receptor Nectin-1. PLoS Pathogens, 7, e1002277. http://dx.doi.org/10.1371/journal.ppat.1002277

[78] Braun, E., Zimmerman, T., Ben Hur, T., Reinhartz, E., Fellig, Y., Panet, A. and Stiener, I. (2006) Neurotropism of Herpes Simplex Virus Type 1 in Brain Organ Cultures. The Journal of General Virology, 87, 2827-2837. http://dx.doi.org/10.1099/vir.0.81850-0

[79] Nakano, K., Asano, R., Tsumoto, K., Kwon, H., Goins, W.F., Kumagai, I., Cohen, J.B. and Glorioso, J.B. (2005) Herpes Simplex Virus Targeting to the EGF Receptor by a gD-Specific Soluble Bridging Molecule. Molecular Therapy, 11, 617-626. http://dx.doi.org/10.1016/j.ymthe.2004.12.012

[80] Heessen, S. and Fornerod, M. (2007) The Inner Nuclear Envelope as a Transcription Factor Resting Place. EMBO Reports, 8, 914-919. http://dx.doi.org/10.1038/sj.embor.7401075

[81] Nettelbeck, D., Jérôme, V. and Müller, R. (2000) Gene Therapy: Designer Promoters for Tumour Targeting. Trends in Genetics, 16, 174-181. http://dx.doi.org/10.1016/S0168-9525(99)01950-2

[82] Wu, L., Johnson, M. and Sato, M. (2003). Transcriptionally Targeted Gene Therapy to Detect and Treat Cancer. Trends in Molecular Medicine, 9, 421-429. http://dx.doi.org/10.1016/j.molmed.2003.08.005

[83] Sadeghi, H. and Hitt, M. (2005) Transcriptionally Targeted Adenovirus Vectors. Current Gene Therapy, 5, $411-427$. http://dx.doi.org/10.2174/1566523054546189

[84] Hardcastle, J., Kurozumi, K., Chiocca, E.A. and Kaur, B. (2007) Oncolytic Viruses Driven by Tumor-Specific Promoters. Current Cancer Drug Targets, 7, 181-189. http://dx.doi.org/10.2174/156800907780058880

[85] Rodriguez, R., Schuur, E.R., Lim, H.Y., Henderson, G.A., Simons, J.W. and Henderson, D.R. (1997) Prostate Attenuated Replication Competent Adenovirus (ARCA) CN706: A Selective Cytotoxic for Prostate-Specific Antigen-Positive Prostate Cancer Cells. Cancer Research, 57, 2559-2563. 
[86] Vile, R. and Hart, I. (1993) Use of Tissue-Specific Expression of the Herpes Simplex Virus Thymidine Kinase Gene to Inhibit Growth of Established Murine Melanomas Following Direct Intratumoral Injection of DNA. Cancer Research, 53, 3860-3864.

[87] Miyatake, S., Iyer, A., Martuza, R.L. and Rabkin, S.D. (1997) Transcriptional Targeting of Herpes Simplex Virus for Cell-Specific Replication. Journal of Virology, 71, 5124-5132.

[88] Nettelbeck, D., Rivera, A., Balagué, C., Alemany, R. and Curiel, D. (2002) Novel Oncolytic Adenoviruses Targeted to Melanoma: Specific Viral Replication and Cytolysis by Expression of E1A Mutants from the Tyrosinase Enhancer/Promoter. Cancer Research, 62, 4663-4670.

[89] Matsubara, S., Wada, Y., Gardner, T.A., Egawa, M., Park, M.S., Hsieh, C.L., Zhau, H.E., Kao, C., Kamidono, S., Gillenwater, J.Y and Chung, L.W. (2001) A conditional Replication-Competent Adenoviral Vector, Ad-OC-E1a, to Cotarget Prostate Cancer and Bone Stroma in an Experimental Model of Androgen-Independent Prostate Cancer Bone Metastasis. Cancer Research, 61, 6012-6019.

[90] Kambara, H., Okano, H., Chiocca, E. and Saeki, Y. (2005) An Oncolytic HSV-1 Mutant Expressing ICP34.5 under Control of a Nestin Promoter Increases Survival of Animals Even When Symptomatic from a Brain Tumor. Cancer Research, 65, 2832-2839. http://dx.doi.org/10.1158/0008-5472.CAN-04-3227

[91] Kanai, R., Eguchi, K., Takahashi, M., Goldman, S., Okano, H., Kawase, T. and Yazaki, T. (2006) Enhanced Therapeutic Efficacy of Oncolytic Herpes Vector G207 against Human Non-Small Cell Lung Cancer-Expression of an RNABinding Protein, Musashi1, as a Marker for the Tailored Gene Therapy. The Journal of Gene Medicine, 8, 1329-1340. http://dx.doi.org/10.1002/jgm.965

[92] Logg, C., Logg, A., Matusik, R., Bochner, B. and N. Kasahara. (2002) Tissue-Specific Transcriptional Targeting of a Replication-Competent Retroviral Vector. Journal of Virology, 76, 12783-12791. http://dx.doi.org/10.1128/JVI.76.24.12783-12791.2002

[93] Rodriguez, R., Schuur, E.R., Lim, H.Y., Henderson, G.A., Simons, J.W. and Henderson, D.R. (1997) Prostate Attenuated Replication Competent Adenovirus (ARCA) CN706: A Selective Cytotoxic for Prostate-Specific Antigen-Positive Prostate Cancer Cells. Cancer Research, 57, 2559-63.

[94] Wei, C., Willis, R.A., Tilton, B.R., Looney, R.J., Lord, E.M., Barth, R.K and Frelinger, J.G. (1997) Tissue-Specific Expression of the Human Prostate-Specific Antigen Gene in Transgenic Mice: Implications for Tolerance and Immunotherapy. Proceedings of the National Academy of Sciences of the United States of America, 94, 6369-6374. http://dx.doi.org/10.1073/pnas.94.12.6369

[95] Small, E.J., Carducci, M.A., Burke, J.M., Rodriguez, R., Fong, L., van Ummersen, L., Yu, D.C., Aimi, J., Ando, D., Working, P., Kirn, D and Wilding, G. (2006) A Phase I Trial of Intravenous CG7870, a Replication-Selective, Prostate-Specific Antigen-Targeted Oncolytic Adenovirus, for the Treatment of Hormone-Refractory, Metastatic Prostate Cancer. Molecular Therapy, 14, 107-117. http://dx.doi.org/10.1016/j.ymthe.2006.02.011

[96] Nettelbeck, D. (2008) Cellular Genetic Tools to Control Oncolytic Adenoviruses for Virotherapy of Cancer. Journal of Molecular Medicine, 86, 363-377. http://dx.doi.org/10.1007/s00109-007-0291-1

[97] Kyo, S., Takakura, M., Fujiwara, T. and Inoue, M. (2008) Understanding and Exploiting hTERT Promoter Regulation for Diagnosis and Treatment of Human Cancers. Cancer Science, 99, 1528-1538. http://dx.doi.org/10.1111/j.1349-7006.2008.00878.x

[98] De Benedetti, A. and Graff, J. (2004) eIF-4E Expression and Its Role in Malignancies and Metastases. Oncogene, 23, 3189-3199. http://dx.doi.org/10.1038/sj.onc.1207545

[99] Bilanges, B. and Stokoe, D. (2007) Mechanisms of Translational Deregulation in Human Tumors and Therapeutic Intervention Strategies. Oncogene, 26, 5973-5990. http://dx.doi.org/10.1038/sj.onc.1210431

[100] Sonenberg, N. and Hinnebusch, A. (2009) Regulation of Translation Initiation in Eukaryotes: Mechanisms and Biological Targets. Cell, 136, 731-745. http://dx.doi.org/10.1016/j.cell.2009.01.042

[101] Pickering, B. and Willis, A. (2005) The Implications of Structured 5' Untranslated Regions on Translation and Disease. Seminars in Cell \& Developmental Biology, 16, 39-47. http://dx.doi.org/10.1016/j.semcdb.2004.11.006

[102] Watkins, S. and C. Norbury, C. (2002) Translation Initiation and Its Deregulation during Tumorigenesis. British Journal of Cancer, 86, 1023-1027. http://dx.doi.org/10.1038/sj.bjc.6600222

[103] Berkel, H., Turbat-Herrera, E., Shi, R. and Benedetti, A. (2001) Expression of the Translation Initiation Factor eIF4E in the Polyp-Cancer Sequence in the Colon. Cancer Epidemiology, Biomarkers \& Prevention, 10, 663-666.

[104] Mamane, Y., Petroulakis, E., Rong, L., Yoshida, K., Ler, L.W. and Sonenberg, N. (2004) eIF4E—From Translation to Transformation. Oncogene, 23, 3172-3179. http://dx.doi.org/10.1038/sj.onc.1207549

[105] Lee, C.Y., Bu, L.X., De Benedetti, A., Williams, B.J., Rennie, P.S. and Jia, W.W. (2010) Transcriptional and Translational Dual-Regulated Oncolytic Herpes Simplex Virus Type 1 for Targeting Prostate Tumors. Molecular Therapy: The Journal of the American Society of Gene Therapy, 18, 929-935. http://dx.doi.org/10.1038/mt.2010.26 
[106] Sacks, W., Greene, C., Aschman, D. and Schaffer, P. (1985) Herpes Simplex Virus Type 1 ICP27 Is an Essential Regulatory Protein. Journal of Virology, 55, 796-805.

[107] Zhang, J., Thomas, T., Kasper, S. and Matusik, R. (2000) A Small Composite Probasin Promoter Confers High Levels of Prostate-Specific Gene Expression through Regulation by Androgens and Glucocorticoids in Vitro and in Vivo. Endocrinology, 141, 4698-4710.

[108] Chlebova, K., Bryja, V., Dvorak, P., Kozubik, A., Wilcox, W.R. and Krejci, P. (2008) High Molecular Weight FGF2: The Biology of a Nuclear Growth Factor. Cellular and Molecular Life Sciences, 66, 225-235. http://dx.doi.org/10.1007/s00018-008-8440-4

[109] Mita, A.C., Mita, M.M., Nawrocki, S. and Giles, F.J. (2008) Survivin: Key Regulator of Mitosis and Apoptosis and Novel Target for Cancer Therapeutics. Clinical Cancer Research, 14, 5000-5005.

[110] Ryan, B.M., Donovan, N.O. and Duffy, M.J. (2009) Survivin: A New Target for Anti-Cancer Therapy. Cancer Treatment Reviews, 35, 553-562. http://dx.doi.org/10.1016/j.ctrv.2009.05.003

[111] Pennati, M., Folini, M. and Zaffaroni, N. (2007) Targeting Survivin in Cancer Therapy: Fulfilled Promises and Open Questions. Carcinogenesis, 28, 1133-1139. http://dx.doi.org/10.1093/carcin/bgm047

[112] Fukuda, S. and Pelus, L.M. (2006) Survivin, a Cancer Target with an Emerging Role in Normal Adult Tissues. Molecular Cancer Therapeutics, 5, 1087-1098. http://dx.doi.org/10.1158/1535-7163.MCT-05-0375

[113] Mull, A.N., Klar, A. and Navara, C.S. (2014) Differential Localization and High Expression of SURVIVIN Splice Variants in Human Embryonic Stem Cells but Not in Differentiated Cells Implicate a Role for SURVIVIN in Pluripotency. Stem Cell Research, 12, 539-549. http://dx.doi.org/10.1016/j.scr.2014.01.002

[114] Hernandez, J.M., Farma, J.M., Coppola, D., Hakam, A., Fulp, W.J., Chen, D.T., Siegel, E.M., Yeatman, T.J. and Shibata, D. (2011) Expression of the Antiapoptotic Protein Survivin in Colon Cancer. Clinical Colorectal Cancer, 10, 188-193. http://dx.doi.org/10.1016/j.clcc.2011.03.014

[115] Krieg, A., Werner, T.A., Verde, P.E., Stoecklein, N.H. and Knoefel, W.T. (2013) Prognostic and Clinicopathological Significance of Survivin in Colorectal Cancer: A Meta-Analysis. PLoS ONE, 8, e65338. http://dx.doi.org/10.1371/journal.pone.0065338

[116] Kawasaki, H., Altieri, D.C., Lu, C.D., Toyoda, M., Tenjo, T. and Tanigawa, N. (1998) Inhibition of Apoptosis by Survivin Predicts Shorter Survival Rates in Colorectal Cancer. Cancer Research, 58, 5071-5074.

[117] Li, F. and Altieri, D. (1999) Transcriptional Analysis of Human Survivin Gene Expression. Biochemical Journal, 344, 305-311. http://dx.doi.org/10.1042/0264-6021:3440305

[118] Kamizono, J., Nagano, S., Murofushi, Y., Komiya, S., Fujiwara, H., Matsuishi, T. and Kosai, K. (2005) Survivin-Responsive Conditionally Replicating Adenovirus Exhibits Cancer-Specific and Efficient Viral Replication. Cancer Research, 65, 5284-5291. http://dx.doi.org/10.1158/0008-5472.CAN-04-2657

[119] Zhu, Z.B., Makhija, S.K., Lu, B., Wang, M., Kaliberova, L., Liu, B., Rivera, A.A., Nettelbeck, D.M., Mahasreshti, P.J., Leath III, C.A., Barker, S., Yamaoto, M., Li, F., Alvarez, R.D. and Curiel, D.T. (2004) Transcriptional Targeting of Tumors with a Novel Tumor-Specific Survivin Promoter. Cancer Gene Therapy, 11, 256-262. http://dx.doi.org/10.1038/sj.cgt.7700679

[120] Ulasov, I., Sonabend, A., Nandi, S., Khramtsov, A., Han, Y. and Lesniak, M. (2009) Combination of Adenoviral Virotherapy and Temozolomide Chemotherapy Eradicates Malignant Glioma through Autophagic and Apoptotic Cell Death in Vivo. British Journal of Cancer, 100, 1154-1164. http://dx.doi.org/10.1038/sj.bjc.6604969

[121] Ahn, B.C., Ronald, J.A., Kim, Y.I., Katzenberg, R., Singh, A., Paulmurugan, R., Ray, S., Hofmann, L.V. and Gambhir, S.S. (2011) Potent, Tumor-Specific Gene Expression in an Orthotopic Hepatoma Rat Model Using a Survivin-Targeted, Amplifiable Adenoviral Vector. Gene Therapy, 18, 606-612. http://dx.doi.org/10.1038/gt.2011.5

[122] Okhi, R., Tsurimoto, T and Ishikawa, F. (2001) In Vitro Reconstitution of the End Replication Problem. Molecular Cell Biology, 21, 5753-5766. http://dx.doi.org/10.1128/MCB.21.17.5753-5766.2001

[123] Cong, Y.S., Wen, J. and Bacchetti, S. (1999) The Human Telomerase Catalytic Subunit hTERT: Organization of the Gene and Characterization of the Promoter. Human Molecular Genetics, 8, 137-142. http://dx.doi.org/10.1093/hmg/8.1.137

[124] Harley, C.B. (2008) Telomerase and Cancer Therapeutics. Nature Reviews Cancer, 8, 167-179. http://dx.doi.org/10.1038/nrc2275

[125] Gellert, G.C., Jackson, J.R., Dikmen, Z.G., Wright, W.E. and Shay, J.W. (2005) Telomerase as a Therapeutic Target in Cancer. Drug Discovery Today: Disease Mechanisms, 2, 159-164. http://dx.doi.org/10.1016/j.ddmec.2005.05.009

[126] Gertler, R., Rosenberg, R., Stricker, D., Friederichs, J., Hoos, A., Werner, M., Ulm, K., Holzmann, B., Nekarda, H. and Siewert, J.-R. (2004) Telomere Length and Human Telomerase Reverse Transcriptase Expression as Markers for Progression and Prognosis of Colorectal Carcinoma. Journal of Clinical Oncology, 22, 1807-1814.

http://dx.doi.org/10.1200/JCO.2004.09.160 
[127] Bertorelle, R., Briarava, M., Rampazzo, E., Biasini, L., Agostini, M., Maretto, I., Lonardi, S., Friso, M.L., Mescoli, C., Zagonel, V., Nitti, D., De Rossi, A. and Pucciarelli, S. (2013) Telomerase Is an Independent Prognostic Marker of Overall Survival in Patients with Colorectal Cancer. British Journal of Cancer, 108, 278-284. http://dx.doi.org/10.1038/bjc.2012.602

[128] Daniel, M., Peek, G.W. and Tollefsbol, T.O. (2012) Regulation of the Human Catalytic Subunit of Telomerase (hTERT). Gene, 498, 135-146. http://dx.doi.org/10.1016/j.gene.2012.01.095

[129] Poole, J.C., Andrews, L.G. and Tollefsbol, T.O. (2001) Activity, Function, and Gene Regulation of the Catalytic Subunit of Telomerase (hTERT). Gene, 269, 1-12. http://dx.doi.org/10.1016/S0378-1119(01)00440-1

[130] Janknecht, R. (2004) On the Road to Immortality: hTERT Upregulation in Cancer Cells. FEBS Letters, 564, 9-13. http://dx.doi.org/10.1016/S0014-5793(04)00356-4

[131] Kyo, S., Takakura, M., Taira, T., Kanaya, T., Itoh, H., Yutsudo, M., Ariga, H. and Inoue, M. (2000) Sp1 Cooperates with c-Myc to Activate Transcription of the Human Telomerase Reverse Transcriptase Gene (hTERT). Nucleic Acids Research, 28, 669-677. http://dx.doi.org/10.1093/nar/28.3.669

[132] Huang, T.G.G., Savontaus, M.J., Shinozaki, K., Sauter, B.V. and Woo, S.L. (2003) Telomerase-Dependent Oncolytic Adenovirus for Cancer Treatment. Gene Therapy, 10, 1241-1247. http://dx.doi.org/10.1038/sj.gt.3301987

[133] Taki, M., Kagawa, S., Nishizaki, M., Mizuguchi, H., Hayakawa, T., Kyo, S., Nagai, K., Urata, Y., Tanaka, N. and Fujiwara, T. (2005) Enhanced oncolysis by a Tropism-Modified Telomerase-Specific Replication-Selective Adenoviral Agent OBP-405 (“Telomelysin-RGD”). Oncogene, 24, 3130-3140. http://dx.doi.org/10.1038/sj.onc.1208460

[134] Kawashima, T. (2004) Telomerase-Specific Replication-Selective Virotherapy for Human Cancer. Clinical Cancer Research, 10, 285-292. http://dx.doi.org/10.1158/1078-0432.CCR-1075-3

[135] Nemunaitis, J., Tong, A.W., Nemunaitis, M., Senzer, N., Phadke, A.P., Bedell, C., Adams, N., Zhang, Y.A., Maples, P.B., Chen, S., Pappen, B., Burke, J., Ichimaru, D., Urata, Y. and Fujiwara, T. (2010) A Phase I Study of Telomerase-Specific Replication Competent Oncolytic Adenovirus (Telomelysin) for Various Solid Tumors. Molecular Therapy, 18, 429-434. http://dx.doi.org/10.1038/mt.2009.262

[136] Malumbres, M. and Barbacid, M. (2003) RAS Oncogenes: The First 30 Years. Nature Reviews Cancer, 3, 459-465. http://dx.doi.org/10.1038/nrc1097

[137] Downward, J. (2003) Targeting RAS Signaling Pathways in Cancer Therapy. Nature Reviews Cancer, 3, 11-22. http://dx.doi.org/10.1038/nrc969

[138] Rose J.S., Serna, D.S., Martin, L.K., Li, X., Weatherby, L.M., Abdel-Misih, A., Zhao, W. and Bekaii-Saab, T. (2012) Influence of KRAS Mutation Status in Metachronous and Synchronous Metastatic Colorectal Adenocarcinoma. Cancer, 118, 6243-6252. http://dx.doi.org/10.1002/cncr.27666

[139] van Houdt, W.J., Hoogwater, F.J.H., de Bruijn, M.T., Emmink, B.L., Nijkamp, M.W., Raats, D.A.E., van der Groep, P., van Diest, P., Rinkes, I.H.M.B. and Kranenburg, O. (2010) Oncogenic KRAS Desensitizes Colorectal Tumor Cells to Epidermal Growth Factor Receptor Inhibition and Activation. Neoplasia, 6, 443-452.

[140] Rajalingnam, K., Schreck, R., Rapp, U.R. and Albert, Š. (2007) Ras Oncogenes and Their Downstream Targets. Biochimica et Biophysica Acta, 1773, 1177-1195. http://dx.doi.org/10.1016/j.bbamcr.2007.01.012

[141] Karapetis, C.S., Khambata-Ford, S., Jonker, D.J., O’Callaghan, C.J., Tu, D., Tebbutt, N.C., Simes, R.J., Chalchal, H., Shapiro, J.D., Robitaille, S., Price, T.J., Shepherd, L., Au, H-J.J., Langer, D., Moore, M.J. and Zalcberg, J.R. (2008) K-ras Mutations and Benefit from Cetuximab in Advanced Colorectal Cancer. The New England Journal of Medicine, 359, 1757-1765. http://dx.doi.org/10.1056/NEJMoa0804385

[142] Andreyev, H.J., Norman, A.R., Cunningham, D., Oates, J.R. and Clarke, P.A. (1998). Kirsten ras Mutations in Patients with Colorectal Cancer: The Multicenter “RASCAL” Study. Journal of the National Cancer Institute, 90, 675-684. http://dx.doi.org/10.1093/jnci/90.9.675

[143] Neumann, J., Zeindl-Eberhart, E., Kirchner, T. and Jung, A. (2009) Frequency and Type of KRAS Mutations in Routine Diagnostic Analysis of Metastatic Colorectal Cancer. Pathology—Research and Practice, 205, 858-862. http://dx.doi.org/10.1016/j.prp.2009.07.010

[144] Riely, G.J., Kris, M.G., Rosenbaum, D., Marks, J., Li, A., Chitale, D.A., Nafa, K., Riedel, E.R., Hsu, M., Pao, W., Miller, V.A. and Ladanyi, M. (2008) Frequency and Distinctive Spectrum of KRAS Mutations in Never Smokers with Lung Adenocarcinoma. Clinical Cancer Research, 14, 5731-5734. http://dx.doi.org/10.1158/1078-0432.CCR-08-0646

[145] Roberts, M.S., Lorence, R.M., Groene, W.S. and Bamat, M.K. (2006) Naturally Oncolytic Viruses. Current Opinion in Molecular Therapeutics, 8, 314-321.

[146] Comins, C., Heinemann, L., Harrington, K., Melcher, A., De Bono, J. and Pandha, H. (2008) Reovirus: Viral Therapy for Cancer “as Nature Intended”. Clinical Oncology, 20, 548-554. http://dx.doi.org/10.1016/j.clon.2008.04.018

[147] Strong, J.E., Coffey, M.C., Tang, D., Sabinin, P. and Lee, P.W. (1998) The Molecular Basis of Viral Oncolysis: Usurpation of the Ras Signaling Pathway by Reovirus. The EMBO Journal, 17, 3351-3362. 
http://dx.doi.org/10.1093/emboj/17.12.3351

[148] Maitra, R., Ghalib, M.H. and Goel, S. (2012) Reovirus: A Targeted Therapeutic-Progress and Potential. Molecular Cancer Research, 10, 1514-1525. http://dx.doi.org/10.1158/1541-7786.MCR-12-0157

[149] Gollamudi, R., Ghalib, M.H., Desai, K.K., Chaudhary, I., Wong, B., Einstein, M., Coffey, M., Gill, G.M., Mettinger, K., Mariadason, J.M., Mani, S. and Goel, S. (2010) Intravenous Administration of Reolysin ${ }^{\circledR}$, a Live Replication Competent RNA Virus Is Safe in Patients with Advanced Solid Tumors. Investigational New Drugs, 28, 641-649. http://dx.doi.org/10.1007/s10637-009-9279-8

[150] Galanis, E., Markovic, S.N., Suman, V.J., Nuovo, G.J., Vile, R.G., Kottke, T.J., Nevala, W.K., Thompson, M.A., Lewis, J.E., Rumilla, K.M., Roulstone, V., Harrington, K., Linette, G.P., Maples, W.J., Coffey, M., Zweibel, J. and Kendra, K. (2012) Phase II Trial of Intravenous Administration of REOLYSIN® (Reovirus Serotype-3-Dearing Strain) in Patients with Metastatic Melanoma. Molecular Therapy, 20, 1998-2003. http://dx.doi.org/10.1038/mt.2012.146

[151] Vermeulen, L., De Sousa, E., Melo, F., van der Heijden, M., Cameron, K., de Jong, J.H., Borovski, T., Tuynman, J.B., Todaro, M., Merz, C., Rodermond, H., Sprick, M.R., Kemper, K., Richel, D.J., Stassi, G. and Medema, J.P. (2010) Wnt Activity Defines Colon Cancer Stem Cells and Is Regulated by the Microenvironment. Nature Cell Biology, 12, 468-476. http://dx.doi.org/10.1038/ncb2048

[152] Suzuki, H., Watkins, D.N., Jair, K.-W.W., Schuebel, K.E., Markowitz, S.D., Chen, W.D., Pretlow, T.P., Yang, B., Akiyama, Y., van Engeland, M., Toyota, M., Tokino, T., Hinoda, Y., Imai, K., Herman, J.G. and Baylin, S.B. (2004) Epigenetic Inactivation of SFRP Genes Allows Constitutive WNT Signaling in Colorectal Cancer. Nature Genetics, 36, 417-422. http://dx.doi.org/10.1038/ng1330

[153] Clevers, H. (2006) Wnt/ $\beta$-Catenin Signaling in Development and Disease. Cell, 127, 469-480. http://dx.doi.org/10.1016/j.cell.2006.10.018

[154] Segditsas, S. and Tomlinson, I. (2006) Colorectal Cancer and Genetic Alterations in the Wnt Pathway. Oncogene, 25, 7531-7537. http://dx.doi.org/10.1038/sj.onc.1210059

[155] Clevers, H. and Nusse, R. (2012) Wnt/ $\beta$-Catenin Signaling and Disease. Cell, 149, 1192-1205. http://dx.doi.org/10.1016/j.cell.2012.05.012

[156] Li, V.S., Ng, S.S., Boersema, P.J., Low, T.Y., Karthaus, W.R., Gerlach, J.P., Mohammed, S., Heck, A.J.R., Maurice, M.M., Mahmoudi, T. and Clevers, H. (2012) Wnt Signaling through Inhibition of $\beta$-Catenin Degradation in an Intact Axin1 Complex. Cell, 149, 1245-1256. http://dx.doi.org/10.1016/j.cell.2012.05.002

[157] Aberle, H., Bauer, A., Stappert, J. Kispert, A. and Kemler, R. (1997) $\beta$-Catenin Is a Target for the Ubiquitin-Proteasome Pathway. The EMBO Journal, 16, 3797-3804. http://dx.doi.org/10.1093/emboj/16.13.3797

[158] Narayan, S. and Roy, D. (2003) Role of APC and DNA Mismatch Repair Genes in the Development of Colorectal Cancers. Molecular Cancer, 2, 15 p. http://www.molecular-cancer.com/content/2/1/41

[159] Naik, S. and Piwnica-Worms, D. (2007) Real-Time Imaging of $\beta$-Catenin Dynamics in Cells and Living Mice. Proceedings of the National Academy of Sciences of the United States of America, 44, 17465-17470. http://dx.doi.org/10.1073/pnas.0704465104

[160] Sprowl, S. and Waterman, M.L. (2013) Past Visits Present: TCF/LEFs Partner with ATFs for $\beta$-Catenin-Independent Activity. PLoS Genetics, 9, e1003745. http://dx.doi.org/10.1371/journal.pgen.1003745

[161] Daniels, D.L. and Weis, W.I. (2005) $\beta$-Catenin Directly Displaces Groucho/TLE Repressors from Tcf/Lef in Wnt-Mediated Transcription Activation. Nature Structural and Molecular Biology, 12, 364-371. http://dx.doi.org/10.1038/nsmb912

[162] Galiatsatos, P. and Foulkes, W.D. (2006) Familial Adematous Polyposis. The American Journal of Gastroenterology, 101, 385-398. http://dx.doi.org/10.1111/j.1572-0241.2006.00375.x

[163] Fearnhead, N.S., Britton, M.P. and Bodmer, W.F. (2001) The ABC of APC. Human Molecular Genetics, 10, $721-733$. http://dx.doi.org/10.1093/hmg/10.7.721

[164] Fuerer, C. and Iggo, R. (2004) 5-Fluorocytosine Increases the Toxicity of Wnt-Targeting Replicating Adenoviruses That Express Cytosine Deaminase as a Late Gene. Gene Therapy, 11, 142-151. http://dx.doi.org/10.1038/sj.gt.3302148

[165] Toth, K., Djeha, H., Ying, B., Tollefson, A.E., Kuppuswamy, M., Doronin, K., Krajcsi, P., Lipinski, K., Wrighton, C.J. and Wold, W.S. (2004) An Oncolytic Adenovirus Vector Combining Enhanced Cell-to-Cell Spreading, Mediated by the ADP Cytolytic Protein, with Selective Replication in Cancer Cells with Deregulated Wnt Signaling. Cancer Research, 64, 3638-3644. http://dx.doi.org/10.1158/0008-5472.CAN-03-3882

[166] Abbosh, P.H., Li, X., Li, L., Gardner, T.A., Kao, C. and Nephew, K.P. (2007) A Conditionally Replicative, Wnt/ $\beta$ Catenin Pathway-Based Adenovirus Therapy for Anaplastic Thyroid Cancer. Cancer Gene Therapy, 14, 399-408. http://dx.doi.org/10.1038/sj.cgt.7701024

[167] Kuroda, T., Rabkin, S.D. and Martuza, R.L. (2006) Effective Treatment of Tumors with Strong Beta-Catenin/T-Cell Factor Activity by Transcriptionally Targeted Oncolytic Herpes Simplex Virus Vector. Cancer Research, 66, 10127- 
10135. http://dx.doi.org/10.1158/0008-5472.CAN-06-2744

[168] Pol, J.G., Rességuier, J. and Lichty, B.D. (2011) Oncolytic Viruses: A Step into Cancer Immunotherapy. Virus Adaptation and Treatment, 2, 1-21.

[169] Heo, J., Reid, T., Ruo, L., Breitbach, C.J., Rose, S., Bloomston, M., Cho, M., Lim, H.Y., Chung, H.C., Kim, C.W., Burke, J., Lencioni, R., Hickman, T., Moon, A., Lee, Y.S., Kim, M.K., Daneshmand, M., Dubois, K., Longpre, L., Ngo, M., Rooney, C., Bell, J.C., Rhee, B.-G., Patt, R., Hwang, T.-H. and Kirn, D.H. (2013) Randomized Dose-Finding Clinical Trial of Oncolytic Immunotherapeutic Vaccinia JX-594 in Liver Cancer. Nature Medicine, 19, 329-338. http://dx.doi.org/10.1038/nm.3089

[170] Wang, C., Xie, J., Guo, J., Manning, H.C., Gore, J.C. and Guo, N. (2012) Evaluation of CD44 and CD133 as Cancer Stem Cell Markers for Colorectal Cancer. Oncology Reports, 28, 1301-1308.

[171] Koltsova, E.K. and Grivennikov, S.I. (2014) IL-22 Gets to the Stem of Colorectal Cancer. Immunity, 40, 639-641. http://dx.doi.org/10.1016/j.immuni.2014.04.014

[172] Todaro, M., Gaggianesi, M., Catalano, V., Benfante, A., Iovino, F., Biffoni, M., Apuzzo, T., Sperduti, I., Volpe, S., Cocorullo, G., Gulotta, G., Dieli, F., Maria, R.D. and Stassi, G. (2014) CD44v6 Is a Marker of Constitutive and Reprogrammed Cancer Stem Cells Driving Colon Cancer Metastasis. Cancer Stem Cell, 3, 342-356. http://dx.doi.org/10.1016/j.stem.2014.01.009

[173] Bach, P., Abel, T., Hoffmann, C., Gal, A., Braun, G., Voelker, I., Ball, C.R., Johnston, I.C., Lauer, U.M., Herold-Mende, C., Mühlebach, M.D., Glimm, H. and Buchholz, C.J. (2013) Specific Elimination of CD133 ${ }^{+}$Tumor Cells with Targeted Oncolytic Measles Virus. Cancer Research, 73, 865-874. http://dx.doi.org/10.1158/0008-5472.CAN-12-2221

[174] Ajayyousi, G., Abdulkarim, M., Griffiths, P. and Gumbleton, M. (2012) Pharmaceutical Nanoparticles and the Mucin Biopolymer Barrier. Bioimpacts, 2, 173-174. 


\section{List of Abbreviations Used}

Ad35: adenovirus serotype 35

Ad5: adenovirus serotype 5

APC: adenomatous polyposis coli

BAP: biotin acceptor peptide

BIRC5: baculoviral inhibitor of apoptosis repeat-containing 5

CAR: Coxsackievirus and adenovirus receptor

CRC: colorectal cancer

CSC: cancer stem cell

EGF: epidermal growth factor

EGFR: epidermal growth factor receptor

eIF-4E: eukaryotic initiation factor $4 \mathrm{E}$

FGF: fibroblast growth factor

FGFR: fibroblast growth factor receptor

GTPase: guanosine triphosphate hydrolase

HA: hemagglutinin

HSV: herpes simplex virus

HSV-1 gD: herpes simplex virus 1glycoprotein D

hTERT: human telomerase reverse transcriptase

IAP: inhibitor of apoptosis

IFN $\alpha / \beta$ : interferon alpha, interferon beta

KRAS: Kirsten-ras GTPase (also referred to as Ki-ras and C-KI-RAS2)

LCMV: lymphocytic choriomeningitis virus

LCMV-GP: lymphocytic choriomeningitis virus coat glycoprotein

NA: neuraminidase

PEG: polyethylene glycol

pHPMA: N-[2-hydroxypropyl] methacrylamide

PKR: protein kinase RNA-activated

PSA: prostate-specific antigen

RCOV: replication-competent oncolytic virus

Tcf/Lef: T cell factor/lymphoid enhancer binding factor

TIC: tumor-initiating cell

TK: thymidine kinase

UTR: untranslated region

VACV: vaccinia virus

VEGF: vascular endothelial growth factor

VSIV: vesicular stomatitis Indiana virus

Wnt: Wingless-related integration site 
Scientific Research Publishing (SCIRP) is one of the largest Open Access journal publishers. It is currently publishing more than 200 open access, online, peer-reviewed journals covering a wide range of academic disciplines. SCIRP serves the worldwide academic communities and contributes to the progress and application of science with its publication.

Other selected journals from SCIRP are listed as below. Submit your manuscript to us via either submit@scirp.org or Online Submission Portal.
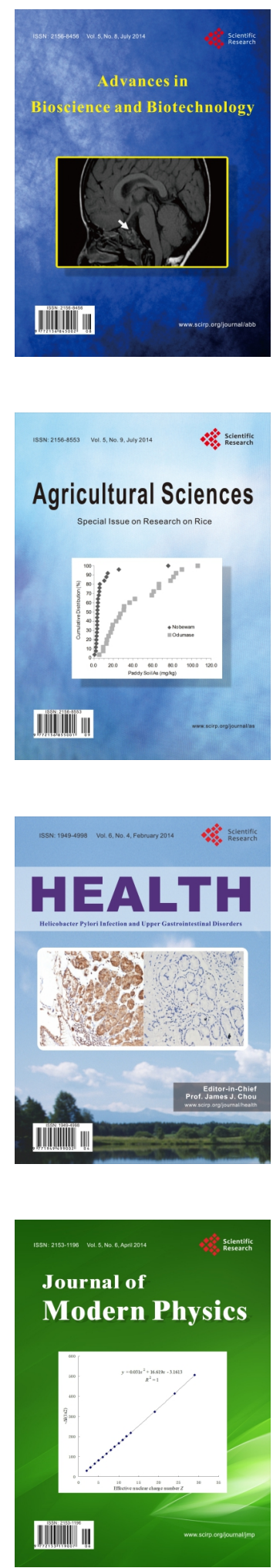
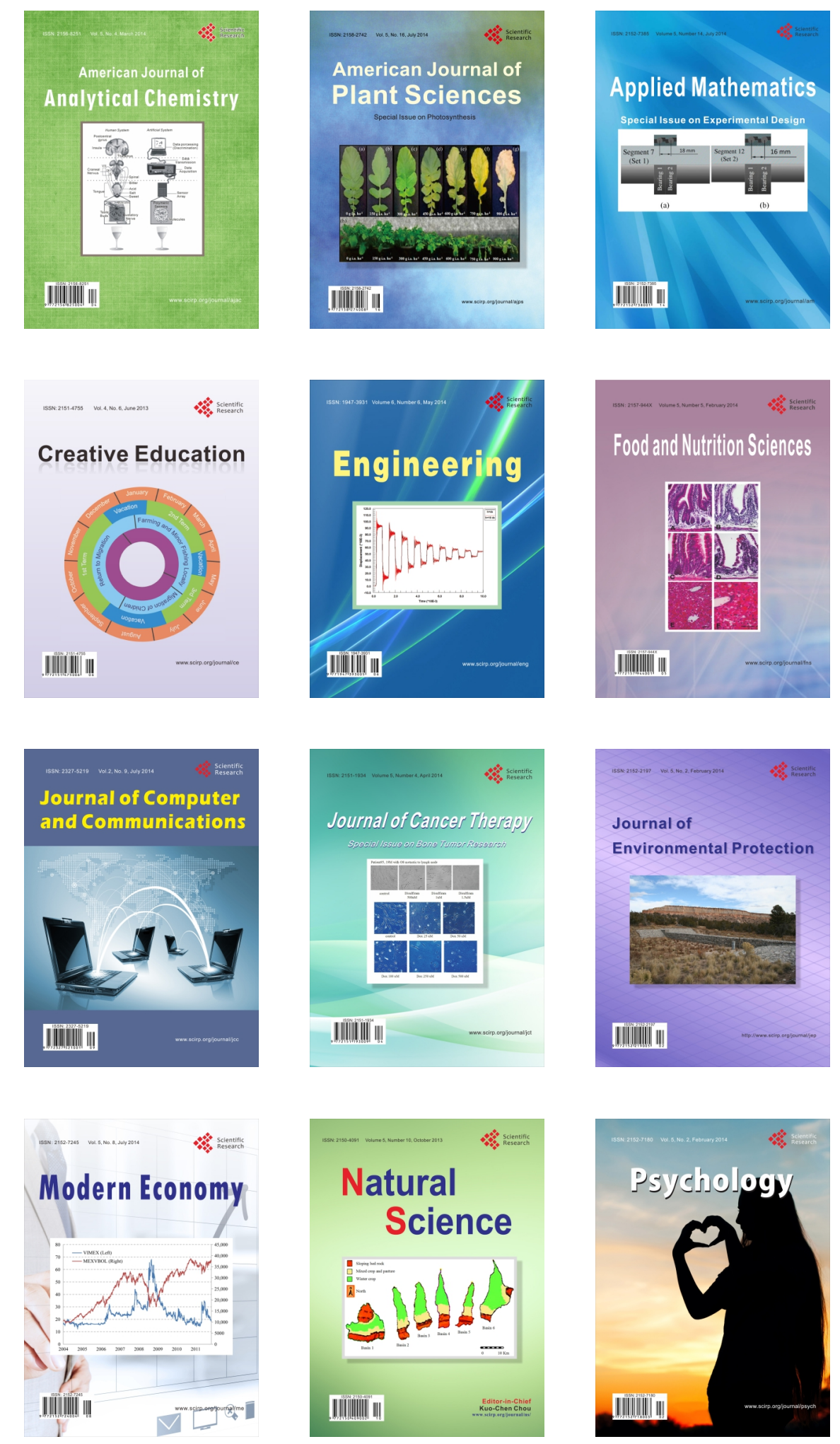